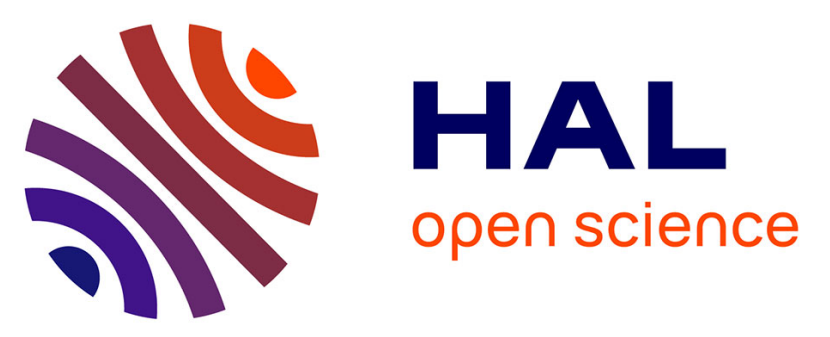

\title{
An early extensional event of the South China block during the late Mesozoic recorded by the emplacement of the late Jurassic syntectonic hengshan composite granitic massif (Hunan, SE China)
}

Wei Wei, Yan Chen, Michel Faure, Guillaume Martelet, Wei Lin, Qingchen Wang, Quanren Yan, Quanlin Hou

\section{To cite this version:}

Wei Wei, Yan Chen, Michel Faure, Guillaume Martelet, Wei Lin, et al.. An early extensional event of the South China block during the late Mesozoic recorded by the emplacement of the late Jurassic syntectonic hengshan composite granitic massif (Hunan, SE China). Tectonophysics, 2016, 672-673, pp.50-67. 10.1016/j.tecto.2016.01.028 . insu-01265788

\section{HAL Id: insu-01265788 \\ https://hal-insu.archives-ouvertes.fr/insu-01265788}

Submitted on 1 Feb 2016

HAL is a multi-disciplinary open access archive for the deposit and dissemination of scientific research documents, whether they are published or not. The documents may come from teaching and research institutions in France or abroad, or from public or private research centers.
L'archive ouverte pluridisciplinaire $\mathbf{H A L}$, est destinée au dépôt et à la diffusion de documents scientifiques de niveau recherche, publiés ou non, émanant des établissements d'enseignement et de recherche français ou étrangers, des laboratoires publics ou privés.

\section{(이) $\$$}

Distributed under a Creative Commons Attribution - NonCommercial - NoDerivatives $\mid 4.0$ 


\section{Accepted Manuscript}

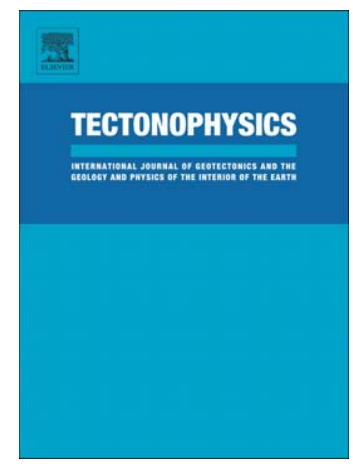

An early extensional event of the South China block during the late Mesozoic recorded by the emplacement of the late Jurassic syntectonic hengshan composite granitic massif (Hunan, SE China)

Wei Wei, Yan Chen, Michel Faure, Guillaume Martelet, Wei Lin, Qingchen Wang, Quanren Yan, Quanlin Hou

\begin{tabular}{|c|c|}
\hline $\begin{array}{l}\text { PII: } \\
\text { DOI: } \\
\text { Reference: }\end{array}$ & $\begin{array}{l}\text { S0040-1951(16)00069-X } \\
\text { doi: } 10.1016 / \text { j.tecto.2016.01.028 } \\
\text { TECTO 126926 }\end{array}$ \\
\hline To appear in: & Tectonophysics \\
\hline Received date: & 7 September 2015 \\
\hline Revised date: & 14 January 2016 \\
\hline Accepted date: & 20 January 2016 \\
\hline
\end{tabular}

Please cite this article as: Wei, Wei, Chen, Yan, Faure, Michel, Martelet, Guillaume, Lin, Wei, Wang, Qingchen, Yan, Quanren, Hou, Quanlin, An early extensional event of the South China block during the late Mesozoic recorded by the emplacement of the late Jurassic syntectonic hengshan composite granitic massif (Hunan, SE China), Tectonophysics (2016), doi: 10.1016/j.tecto.2016.01.028

This is a PDF file of an unedited manuscript that has been accepted for publication. As a service to our customers we are providing this early version of the manuscript. The manuscript will undergo copyediting, typesetting, and review of the resulting proof before it is published in its final form. Please note that during the production process errors may be discovered which could affect the content, and all legal disclaimers that apply to the journal pertain. 


\title{
An early extensional event of the South China Block during the Late Mesozoic
}

recorded by the emplacement of the Late Jurassic syntectonic Hengshan

\section{Composite Granitic Massif (Hunan, SE China)}

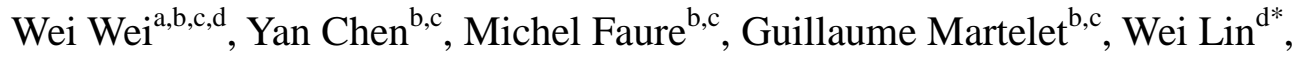
Qingchen Wang ${ }^{\mathrm{d}}$, Quanren Yan ${ }^{\mathrm{a}}$, and Quanlin Hou ${ }^{\mathrm{a}}$.

${ }^{a}$ Key Laboratory of Computational Geodynamics, University of Chinese Academy of Sciences, Beijing 100049, China

${ }^{\mathrm{b}}$ Université d'Orléans, ISTO, UMR 7327, 45071 Orléans, France

${ }^{\mathrm{c}}$ CNRS/BRGM/INSU, ISTO, UMR 7327, 45071 Orléans, France

${ }^{\mathrm{d}}$ SKL, Institute of Geology and Geophysics, Chinese Academy of Sciences, Beijing 100029, China

*Corresponding author: linwei@mail.iggcas.ac.cn

\begin{abstract}
:
Continental scaled extension is the major Late Mesozoic (Jurassic and Cretaceous) tectonic event in East Asia, characterized by faulting, magmatic intrusions and half-grabens in an area with a length of $>5000 \mathrm{~km}$ and a width of $>1000 \mathrm{~km}$. Numerous studies have been conducted on this topic in the South China Block (SCB), However, the space and time ranges of the compressional or extensional regimes of the SCB during the Jurassic are still unclear, partly due to the lack of structural data.
\end{abstract}


The emplacement fabrics of granitic plutons can help determine the regional tectonic background. In this study, a multidisciplinary approach, including Anisotropy of Magnetic Susceptibility (AMS), macro and micro structural analyses, quartz c-axis preferred orientation, gravity modeling and monazite EPMA dating, was conducted on the Hengshan composite granitic massif in SCB that consists of the Triassic Nanyue biotite granitic pluton and the Late Jurassic Baishifeng two-mica granitic pluton. The magnetic fabrics are characterized by a consistent NW-SE oriented lineation and weakly inclined foliation. A dominant high temperature deformation with a top-to-the-NW shear sense is identified for both plutons. The deformation increasing from the center of the Baishifeng pluton to its western border is associated to the development of the West Hengshan Boundary Fault (WHBF). The gravity modeling shows a "saw tooth-shaped" NE-SW oriented structure of the Baishifeng pluton, which may be considered as NE-SW oriented tension-gashes formed due to the NW-SE extension. All results show that the Triassic Nanyue pluton was deformed under post-solidus conditions by the WHBF coeval with the emplacement of the Late Jurassic Baishifeng pluton. All these observations comply with the NW-SE extensional tectonics coeval with the emplacement of the Baishifeng pluton, which argues that the NW-SE crustal stretching started since the Late Jurassic, at least in this part of the SCB.

Keywords: South China Block, Hengshan composite granitic massif, syntectonic pluton, Anisotropy of Magnetic Susceptibility (AMS), gravity modeling, Mesozoic 
extensional tectonics.

\section{Introduction}

Continental scaled tectonics, characterized by ductile faults, numerous plutonic intrusions and sedimentary half-grabens, represent the major Mesozoic tectonic event in East Asia. This event can be observed all along the East Asia continental margin of more than $5000 \mathrm{~km}$, and it extends continentwards about $1000 \mathrm{~km}$ in South China, and even more than $2500 \mathrm{~km}$ in North China, Mongolia and Siberia (e.g. Zhou and Li 2000; Ren et al., 2002; Meng, 2003; Wu et al., 2005; Wang et al., 2006; Li and Li 2007; Zhang et al., 2008; Davis and Darby, 2010; Zhou et al., 2012; Dash et al., 2015; Wang et al., 2015). Due to the representatives of this tectonic event, and the related contemporary ore deposit forming processes, the Jurassic and Cretaceous tectonic regime of the South China Block (SCB) has attracted great interest in the geological community (e.g. Zhou and Li, 2000; Zhou et al., 2006; Li and Li, 2007; Shu et al., 2007 and 2009; Li et al., 2010a; Mao et al., 2011). Although a NE-SW strike-slip regime was invoked to account for the Cretaceous tectonics of the SE part of SCB decades ago (e.g. Xu et al., 1987; Gilder et al., 1996; Li et al., 2001), now most of the workers argue for a dominant NW-SE extensional regime during the Cretaceous (e.g. Gilder et al., 1991; Goodell et al., 1991; Zhou and Li, 2000; Lin et al., 2000; Faure et al., 2003; Li and Li, 2007; Mercier et al., 2007; Shu et al., 2009; Wei et al., 2014a; Lin et al., 2015). However, the Jurassic tectonics in SCB is still under debate. Based on the basin analysis, it has been proposed that extensional basins (half grabens) were 
already developed since the Middle Jurassic in the eastern SCB in the Hunan, Jiangxi and Guangdong provinces (Shu et al., 2007 and 2009), the bimodal volcanic sequences that erupted in the Nanling range also support this view (Zhou et al., 2006). In the western SCB, the structural analysis of the Tancheng-Lujiang fault shows a sinistral strike-slip in the Late Jurassic (Zhu et al., 2010). In the Yanma basin located in the western SCB, the kinematic analysis of brittle faults also indicates that the Mid-Late Jurassic was still under an W-E compressional regime (Li et al., 2012a). Further west, in the eastern part of the Sichuan basin, the Jurassic and the Early Cretaceous strata were involved in the fold-and-trust belt, and were overlain by the Late Cretaceous beds that indicates the NW-SE compression regime lasted up to the Early Cretaceous (Yan et al., 2003). The above results, show that during the Jurassic, the eastern part of the SCB experienced extension, while on the contrary, the western part of the SCB was still dominated by a compressional regime. However, the limit between the areas under compression and extension during the Jurassic was not clearly documented, thus systematic structural analysis needs to be conducted on the Jurassic structures in the central SCB.

As illustrated in numerous orogens throughout the world, the internal fabric and the shape of a granitic massif record the regional tectonic regime coeval with its emplacement (e. g. Faure, 1995; Bouchez and Gleizes, 1995; Archanjo and Bouchez, 1997; Callot et al., 2001; Neves et al., 2003; Talbot et al., 2005a; De Oliveira et al., 2010; Turrillot et al., 2011; Wei et al., 2014b). In order to figure out the tectonic regime in the central $\mathrm{SCB}$, and to better constrain the tectonic system at the scale of 
the entire SCB, we have conducted a multidisciplinary study including field structural observation, AMS measurement, microscopic observation, measurement of quartz $\mathrm{C}$-axis lattice preferred orientation, gravity modeling and monazite EPMA U-Th- $\mathrm{Pb}$ chemical dating on the Hengshan composite granitic massif that intruded in the central SCB. The following questions are addressed:

(1) What is the architecture of the Hengshan composite granitic massif?

(2) What is the relationship between the emplacement of the Hengshan composite granitic massif and the development of the ductile shear zone along its western boundary?

(3) What was the regional tectonic regime during the emplacement of the Hengshan composite granitic massif?

\section{Geological setting}

\subsection{Geological framework of the study area}

The Hengshan composite granitic massif intrudes into the Jiangnan orogenic belt in the central SCB, which is an Early Neoproterozoic collision orogen that merged the Yangtze and the Cathaysian blocks into the SCB (Li et al., 1994; Charvet et al., 1996; Shu et al., 2006; Li et al., 2009). The crystalline basement of the SCB is represented by Paleoproterozoic TTG gneiss, amphibolites and migmatites (Yu et al., 2007, 2009, 2010; Jiao et al., 2009; Qiu and Gao, 2000). In Eastern Hunan of the central SCB, the Neoproterozoic strata involved in the Jiangnan orogeny experienced a low grade metamorphism (HNBGMR, 1987). 
After the Jiangnan orogeny, a rifting event led to the formation of a NE-SW striking intracontinental basin filled by terrigenous series with ages ranging from the Late Neoproterozoic (Sinian) to Ordovician (Wang and Li, 2003; Shu et al., 2011; Wang et al., 2013). During the Silurian, the central part of the SCB experienced an intracontinental orogeny characterized by the northward subduction of the Cathaysia block (Faure et al., 2009). Since the Devonian, the SCB was unconformably overlain by terrigenous rocks, then a limestone platform developed above the deformed Sinian to Ordovician rocks (JXBGMR, 1984; HNBGMR, 1987; Faure et al., 2009).

During the Early Mesozoic, the SCB was bounded by several orogens, namely the Dabie-Sulu belt in the north, and the collision belt between SCB with the Qiangtang-Indochina block in the east and south (e.g. Mattauer et al., 1985; Li et al., 2012b; Wang et al., 2013; Faure et al., 2014). To the southeast, the tectonic pattern is not settled yet, although most of authors consider a Paleo-Pacific subduction below the SCB, a southeastward subduction of the SCB below the eastern extension of Indochina cannot be ruled out (see discussion in Faure et al., in press). In the Middle Triassic intracontinental Xuefeng belt (Fig. 1a), the intracontinental convergence characterized by southeastward continental subduction of the Paleoproterozoic basement led to a ca $250 \mathrm{~km}$ wide, east or northeast-directed fold-and-thrust belt unconformably covered by the Late Triassic deposits (Faure et al., 1998; Zhang et al., 2009; Li et al., 2010b; Chu et al., 2012). Partly due to the lack of sedimentary deposits, the Jurassic tectonics of the SCB is poorly documented. In the western Hunan, eastern Sichuan, and Guizhou provinces, N-S striking, west-verging folds involving Late 
Triassic and Jurassic series are recognized (Yan et al., 2003; Zhang et al., 2009; Li et al., 2012b). In the central and eastern SCB (Hunan, Guangdong, Jiangxi, Fujian, Zhejiang Provinces), since the Middle Jurassic, the continental red beds inter-bedded with bimodal volcanic rocks crop out along NE-SW striking grabens or half-grabens bounded by brittle or ductile normal faults indicating an extensional tectonic regime (Zhou et al., 2006; Shu et al., 2007 and 2009). However, along the coastal area, the Early Cretaceous rocks, represented by volcanites, pyroclastites, and volcanic-sedimentary deposits related to an NW-directed oceanic subduction below the SCB, underwent a ductile top-to-the-NW shearing developed between 130 and $105 \mathrm{Ma}$ in a compressional setting (Wei et al., 2015). Cretaceous plutons are widespread in SE China. Most of the Early Cretaceous plutons are syntectonic bodies that recorded a NW-SE regional extensional setting coeval with their emplacement (e.g. Lin et al., 2000; Lin et al., 2015, and enclosed references).

\subsection{The Hengshan composite granitic massif}

The Hengshan composite granitic massif is located in the eastern Hunan Province. It intrudes into the Late Neoproterozoic sedimentary series that experienced the long lasting deformation history as discussed above (Fig. 1a). This diamond-shaped massif is composed of the Nanyue biotite granitic pluton and the Baishifeng two-mica granitic pluton on the east and west, respectively (Fig. 1b). The western part of the Baishifeng pluton exposes a gneissic granite with locally an augen structure (Wang, 1990a and b). In recent years, the Nanyue and Baishifeng plutons 
were dated by zircon $\mathrm{U}-\mathrm{Pb}$ method at $230 \pm 2 \mathrm{Ma}$ and $150 \pm 1 \mathrm{Ma}$, respectively (Li et al., 2013). A systematic thermal history study on the Hengshan composite granitic massif argues for a $50^{\circ} \mathrm{C} / \mathrm{Myr}$ to $13^{\circ} \mathrm{C} / \mathrm{Myr}$ cooling rate and experienced $26^{\circ}-50^{\circ}$ eastward tilting and 8-12 km dip-slip displacement (Li et al., in press).

\subsection{The West Henghsan Boundary Fault}

To the west, the Hengshan massif is in contact with the red sedimentary strata of the Zhajiang basin by a mylonitic and cataclasitic zone, called the West Henghsan Boundary Fault (WHBF). This fault is a part of the $600 \mathrm{~km}$ long Xiushui-Yongzhou crustal-scale deep fault (Fig. 1a; HNBGMR, 1987; Zhang, 1994a). Due to this fault activity, the western part of the Baishifeng pluton developed a pervasive ductile deformation. The NNE-SSW striking, WNW dipping foliation contains a down-dip stretching and mineral lineation as indicated by previous studies (Zhang and Zhu, 1989; Xu et al., 1998; Li et al., 2013). Based on quartz vein boudinage, angle of the $\mathrm{S}-\mathrm{C}$ fabrics and porphyroclast axial ratio in augen gneissic two-mica granite, a $10 \mathrm{~km}$ displacement of this ductile shear zone was proposed (Xu et al., 1998). The WHBF experienced thermal fluid activity which led to the metasomatic silicification (e.g. K-feldspar replaced by albite) and formation of albite and Uranium deposits (Xiao, 1989; Zhang, 1994b). Recently, zircon U-Pb dating, mica ${ }^{40} \mathrm{Ar}-{ }^{39} \mathrm{Ar}$ dating and quartz c-axis measurements have been conducted on the WHBF. The results show that the deformation temperature ranged between 400 and $550^{\circ} \mathrm{C}$, the ductile shearing was accommodated by quartz basal <a>, and prism <a> glide developed between 136 and 
$97 \mathrm{Ma}(\mathrm{Li}$ et al., 2013).

\subsection{The Zhajiang basin}

To the west of the WHBF, the Zhajiang basin was filled by red continental debris, provided by piedmont alluvial fans to river and lacustrine facies where many fossils were discovered such as dinosaur eggs and footprints, chara and pollen indicating a Cretaceous age (HNBGMR, 1987). The oldest sedimentary rocks that can be found in the outcrops of this basin belong to the Lower Cretaceous Dongjing Formation that unconformably overlies Neoproterozoic or Paleozoic sedimentary rocks (Fig. 1b; HNBGMR, 1987; Ge et al., 1994).

\section{Structural features of the Hengshan composite granitic massif}

\subsection{The Nanyue pluton}

The major part of the biotite Nanyue pluton is a massive rock with NW-SE striking grey, idiomorphic, 1 to $5 \mathrm{~cm}$ sized K-feldspar megacrysts (Figs. $1 \mathrm{~b}$ and $2 \mathrm{a}$ ). A large number of two-mica aplitic dykes intruded into the biotite granite (Fig. 2a). The gneissic fabric is present only in a few sites near the Zhurong peak which is the highest place in the Hengshan massif (Location 2 in Fig. 1b), and the northwestern corner affected by the WHBF (Location 3 in Fig. 1b). The gneissic granodiorite in the Zhurong peak is featured by the elongation of quartz grains and the $\mathrm{N} 140^{\circ} \mathrm{E}$ preferred orientation of K-feldspar megacryst. On the northwestern corner of the Nanyue pluton, the biotite granite was deformed to gneissic granite with a $\mathrm{N} 20^{\circ} \mathrm{E}$ striking $\mathrm{NW} 20^{\circ}$ dipping foliation. A $\mathrm{N} 290^{\circ} \mathrm{E}$ trending $\mathrm{NW} 20^{\circ}$ plunging mineral lineation represented 
by K-feldspar orientation developed on the foliation plane.

\subsection{The Baishifeng two-mica granitic pluton}

The Baishifeng two-mica pluton can be structurally divided into three parts from east to west, namely, 1) the magmatic texture zone (eastern part of the Baishifeng pluton), 2) the gneissic granite zone, and 3) the mylonitic and cataclastic zone (WHBF; Fig. 1b). The last two zones will be introduced in Section 3.3. The magmatic texture zone of the pluton is featured by euhedral K-feldspar megacrysts, and a weakly developed magmatic foliation featured by oriented micas. In many outcrops, the biotite concentrates to form schlieren. Both the magmatic foliation and schlierens strike NE-SW and dip to the NW (Fig. 2b, Location 4 in Fig. 5b).

\subsection{The gneissic granite zone, the West Hengshan Boundary Fault (WHBF) and the Zhanjiang Basin}

The gneissic granite zone of the Hengshan massif consists of foliated granite in the western part of the Baishifeng pluton and the northwestern corner of the Nanyue pluton (Fig. 1b). Oriented quartz, feldspar and mica define the gneissic foliation that predominantly dips to the NW, and a NW-SE striking stretching and mineral lineation. In the section parallel to the lineation and perpendicular to the foliation (XZ section), the quartz grains exhibit recrystallized texture and a sigmoidal shape with asymmetric tails indicating a top-to-the-NW sense of shear (Fig. 2c; Location 5 in Fig. 1b). The two-mica gneissic granite encloses $\mathrm{cm}$ - to $\mathrm{m}$-sized micaschist xenolith, in which the foliation also dips to NW, while the lineation plunges to the NW (Location 11 in Fig. 
$1 b)$.

In the WHBF, mylonite, ultra-mylonite and cataclasite develop successively from the east to the west. The ultra-mylonitic granite is featured by $\mathrm{mm}$-sized feldspar clasts scattered in a fine grain matrix made of quartz, feldspar and rare mica. Quartz is stretched forming polycrystalline ribbons striking NE-SW and dipping to the NW. Owing to continuous shearing, the mylonitic foliation was bent into inclined fold with axial surface dipping to SE indicating a top-to-the-NW shear sense (Fig. 2d). The WHBF experienced a thermal fluid metasomatism as shown by the presence of abundant dark tourmaline (Fig. 2e).

To the west, a NW-dipping high-angle brittle fault separates the mylonitic granite in the footwall from conglomerate and red coarse clastic sediments of the Zhajiang basin in the hangingwall. On the footwall side, the breccia is made of angular fragments of ultra-mylonitic clasts or white quartz veins with size of ca. $3 \mathrm{~cm}$ usually or even reaching to several tens of $\mathrm{cm}$ (Fig. 2f, Location 6 in Fig. 1b). On the hangingwall side, cracks penetrate the breccia and the matrix of the red conglomerate (Fig. 2g). The sequence of ultra-mylonite, cataclasite and cracked conglomerate illustrates that the tectonic activity along the WHBF evolved from ductile shearing to brittle cracking during the exhumation of the Hengshan massif (Fig. 2h).

The WHBF is not restricted to the boundary between the Hengshan massif and the Zhanjiang basin. Further to the northeast, the WHBF separates the Neoproterozoic country rocks and the Cretaceous Zhanjiang basin. Two small plutons of biotite granite crop out along the fault (Fig. 1b, Location near and north of 7 in Fig. 1b). The 
Neoproterozoic sedimentary sequence was deformed by WHBF to form a NE-SW striking and NW dipping slaty cleavage. Though no lineation or striation has been observed here, along the NW-SE section, which is parallel to the regional shear direction, sigmoidal quartz veins indicate a top-to-the-NW shear sense (Fig. 2i, Location 7 in Fig. 1b). As shown on the 1:200,000 geological map, in the southwestern corner of the Baishifeng pluton, the WHBF splits into two branches. One extends to the southwest along the Cretacous-Neoproterozoic brittle boundary, but it is poorly exposed due to weathering, whereas another branch turns to the southeast along the pluton boundary as a ductile fault. There, mylonites with a NE-SW striking, SW dipping foliation and a subhorizontal stretching lineation are observed (Fig. 1b; HNBGMR, 1973). It is worth to note that in spite of the change of the foliation orientation, the lineation keeps the same trend as in the main part of the WHBF (Location 8 in Fig. 1b).

In the Zhajiang basin, the red sandstone layers near the WHBF dip to the SE as a consequence of the progressive tilting of the strata (Figs. $1 \mathrm{~b}$ and $2 \mathrm{j}$ ). The shape of the Zhajiang basin is rectangular with a NE-SW long side along the WHBF. In its eastern part of the basin, close to the WHBF, the strata dip to the SE with a $30^{\circ}$ to $50^{\circ}$ angle. Inside the basin, the strike of the strata is variable, but the dip varies gently, usually less than $20^{\circ}$, suggesting that the basin structure was controlled by the WHBF. In the western part of the basin, the $10^{\circ}$ to $15^{\circ} \mathrm{SE}$ dipping Cretaceous red strata unconformably overlie the Proterozoic to the Early Jurassic granitic and sedimentary rocks. So the opening of the Zhajiang basin is controlled by the activity of the WHBF. 


\section{The magnetic fabrics of the Hengshan composite granitic massif}

\subsection{Sampling and measurements}

The approach of Anisotropy Magnetic Susceptibility (AMS) is efficient to determine the shear direction in a ductile shear zone (e.g. Ferre et al., 2014). In a granitic pluton, the magnetic fabric pattern can be used to simulate the tectonic regime during the emplacement of the pluton (Bouchez and Gleizes, 1995; Aurejac et al., 2004; Talbot et al, 2005a and b; De Oliveira et al., 2010; Turrillot et al., 2011; Charles et al., 2012). In the Hengshan massif, a previous study has shown that the AMS fabric pattern of the mylonite is consistent with the mineral fabrics observed in the WHBF (Zhang and Zhu, 1989). However, no systematic AMS study on the main body of the Hengshan massif has been carried out yet, where the fabrics are not visible in the field. Thus, the information on the tectonic regime during the emplacement of the Hengshan massif is still lacking. In order to acquire this new information, we used a gasoline driller to conduct an AMS collection of 33 sites covering the Nanyue pluton and the Baishifeng pluton (Table 1). The sites are generally separated by about $2 \mathrm{~km}$. In each site, 5 or 6 cores of $2.5 \mathrm{~cm}$ in diameter have been drilled. The cores are at least $2 \mathrm{~m}$ away from each other. Both magnetic and solar compasses (depending on the weather) were used to measure the orientation of the cores. In the laboratory, each core was cut into standard specimens of $2.2 \mathrm{~cm}$ in length. In total, 282 specimens were prepared (Table 1).

In the Laboratoire de Magnétisme des Roches d'Orléans, a KLY3 kapabridge was 
used to measure both the anisotropy magnetic susceptibility and the bulk susceptibility. The software ANISOFT (offered by AGICO) has been used to conduct Jelinek statistics (Jelinek, 1981) and to calculate the orientation of the three principal axes $\left(\mathrm{k}_{1}\right.$, the long magnetic axis and magnetic lineation; $\mathrm{k}_{2}$, the intermediate magnetic axis; $\mathrm{k}_{3}$, the short magnetic axis and the pole of the magnetic foliation), the shape parameter (T) and the anisotropy degree $\left(\mathrm{P}_{\mathrm{J}}\right)$ of the AMS ellipsoid. In addition, the hysteresis loops of the rocks from the Nanyue and Baishifeng plutons have been measured in the Paleomagnetic laboratory of the Institut de Physique du Globe de Paris.

\subsection{The magnetic susceptibility carrier determination}

As shown in Figure 3 and Table 1, the samples from the Hengshan massif have low bulk susceptibilities ranging from 60 to $200 \times 10^{-6}$ SI for the Nanyue pluton and from 10 to $80 \times 10^{-6} \mathrm{SI}$ for the Beishifeng pluton with few specimens up to $160 \times 10^{-6}$ SI. Generally, the bulk susceptibility of the Nanyue pluton is higher than that of the Baishifeng pluton.

Regardless of the lithology, both hysteresis loops for the Nanyue and Baishifeng plutons display linear shape (Fig. 4), indicating that the susceptibility is mainly carried by paramagnetic minerals, such as biotite or/and amphibole. The higher susceptibility of the Nanyue pluton is obviously related to the larger biotite concentration, as illustrated by the darker colour in the outcrop observation.

\subsection{Results of AMS measurements}

The AMS data of the Nanyue and Baishifeng plutons (Table 1) show that the ellipsoidal confidences ( $a_{95 \max }$ and $a_{95 \min }$ ) of most of site-mean $k_{1}$ and $k_{3}$ are rather 
low $\left(\leq 20^{\circ}\right)$, strengthening confidence of the AMS data of this study and, consequently, the magnetic fabrics may be used to conduct a structural discussion.

The $\mathrm{P}_{\mathrm{J}}$ values are lower than 1.2, except for three specimens from the western part of the Baishifeng pluton belonging to the gneissic granite zone (Fig. 5a, Location 5 in Fig. 1b). No obvious correlation is observed between $\mathrm{P}_{\mathrm{J}}$ and the average magnetic susceptibility (Km; Fig. 5a). The $\mathrm{T}$ values of most specimens are above 0 indicating an oblate predominance of the AMS ellipsoid.

Sampling has been conducted in 13 sites of the Nanyue biotite granitic pluton and 20 sites of the Baishifeng two-mica pluton. Concerning the magnetic fabrics from the Nanyue pluton, the stereographic projection diagrams of site-mean magnetic fabrics show that the poles of the magnetic foliation ( $\mathrm{k}_{3}$ axes) are arranged in the cloud distribution with highly inclined inclinations and their magnetic lineation ( $\mathrm{k}_{1}$ axes) are clustered around NW-SE with gentle plunge (Figs. 6, 7a and 7b). The magnetic fabrics from the Baishifeng pluton are more scattered, with high inclinations of the foliation poles and a general NW-SE oriented cluster of lineation is also identifiable (Figs. $7 \mathrm{c}$ and $7 \mathrm{~d}$ ). The sites that show scatter or inconsistent lineations are located either in the center of the pluton (HY68, HY71, HY79 and HY80 highlighted with dash circle in Fig. 6) or along the boundary of the two plutons (HY53, HY78 highlighted with dash circle in Fig. 6). The magnetic fabrics of these sites may record more magmatic or border effect. Therefore, the general NW-SE lineation trend and gently inclined foliation are considered as the characteristics of magnetic fabrics of the both plutons of the Hengyang massif. 
Plotting all of the magnetic fabrics on the geologic map (Fig. 8), it is easy to observe that near the boundary between the Nanyue and the Baishifeng plutons, the strikes of the magnetic foliations of many sites from the Nanyue pluton strike perpendicular to the boundary (e.g. Sites HY50, HY65, HY76 and HY81 shown in Fig. 6). However, the magnetic foliation of the Baishifeng pluton is parallel to the boundary.

\section{Microscopic observation and kinematics study}

\subsection{Thin section preparation}

In order to observe the kinematics and the deformation styles of the WHBF and to determine whether the origin of the magnetic fabrics are primary ones acquired during the granite emplacement, or secondary ones developed during a subsequent deformation, specimens from 8 sites of the Nanyue pluton and 21 sites of the Baishifeng pluton were selected for microscopic observation. The oriented thin sections are parallel to the mineral or magnetic lineation and perpendicular to the mineral or magnetic foliation (XZ section). In the thin sections from the Baishifeng pluton, 14 come from the WHBF, and 7 are chosen along an E-W profile across the pluton. In the following, we shall discuss the microscopic features of the main bodies of the two plutons and WHBF separately.

\subsection{Deformation styles and kinematics}

In the thin sections from the Nanyue pluton, the K-feldspar grains are cataclazed. The cracks are filled by small K-feldspar fragments (Fig. 9a). A few of feldspar grains 
show undulose extinction and develop recrystallized subgrains with curved boundaries (Fig. 9b), while others develop mechanical twins (Fig. 9c). Biotite shows undulose extinction and its cleavages are straight or bent (Figs. 9b and 9c). Quartz shows undulose extinction and develops subgrains with curved boundaries (Figs. 9b, 9c and 10). Corresponding to the macroscopic observations near the Zhurong peak (Location 2 in Fig. 1b or Location e in Fig. 6), the degree of deformation of the sample HY66 is higher than all the other sites of the Nanyue pluton. In this sample, the foliation marked by the preferred orientation of biotite is well defined; quartz presents "sigmoidal" shapes indicating a top-to-the-NW shear sense. Under the microscope, "sigmoidal" biotites and feldspars also indicate a top-to-the-NW sense of shear (Fig. 9b).

The main body of the Baishifeng two-mica pluton shows an increase of deformation from east to west related to the WHBF. In the eastern part of the Baishifeng pluton, the mineral preferred orientation developed under magmatic conditions. Plagioclase and microcline exhibit magmatic zonations and polysynthetic twins. Biotite and muscovite are idiomorphic with straight cleavage planes defining a magmatic foliation that can be sometimes recognized in the field (Fig. 9d). Contrary to the magmatic texture of other minerals, quartz shows high temperature deformation microstructures such as sharp or weakly undulose extinction with rare subgrains (Fig. 9e), chessboard structure (Fig. 10f), and subeuhedral with weakly curved or sutured boundaries (Figs. 10f-10i).

To the west, in the gneissic zone of the Baishifeng pluton, the average grain size 
is reduced (around 200 um; Fig. 9f). Quartz with undulose extinction and well developed subgrains is elongated parallel to NW-SE. Dynamic recrystallization is marked by small neograins and sutured grain boundaries (Figs. 10j and 10k). Biotite and muscovite grains formed mica fishes shape (Figs. 9f and 9g), again indicating a top-to-the-NW shear sense. Shear bends observed in thin sections from micaschist xenoliths indicate the same shear sense.

The deformation is maximum along the WHBF where the granite becomes mylonitic (Fig. 1b). Under the microscope, fractured feldspars display domino structure indicating a top-to-the-NW shear sense and quartz experienced a dynamically recrystallization (Fig. 9h). Subgrain rotation developed an oblique shape fabric consistent with a top-to-the-NW shearing. On the SW boundary of the Baishifeng pluton, and along the SE branch of the WHBF where a NW-SE foliation and subhorizontal lineation develop, kinematic indicators observed in the mylonite are consistent with a dextral strike-slip (Fig. 9i). However, this shear sense corresponds to a transfer zone of the normal WHBF fault in which the hanging wall moves to the northwest.

\subsection{Quartz c-axis preferred orientation}

Numerous studies have dealt with quartz c-axis patterns, textures and microscopic fabrics in relation with deformation mechanisms, rheological conditions or kinematics (e.g. Stipp et al., 2002; Law, 2014 and enclosed references). Due to the high temperature coeval with its acquisition, the quartz c-axis pattern of a syn-tectonic granitoid is usually featured by c-prism slip and a large opening angle between the 
c-axes maxima (e. g., Duguet and Faure, 2004; Liotta et al., 2008; Menegon et al., 2008; Festa, 2009). In this study, systematic universal stage quartz c-axis measurements coupled with microstructural observations have been carried out along a west-east profile across the Hengshan massif. Five samples (Figs. 10a-10e) belong to the Nanyue pluton, 4 samples are from the magmatic texture zone of the Baishifeng pluton (Figs. 10f-10i) and 2 samples are from the gneissic zone of the Baishifeng pluton (Figs. 10j and 10k; see Fig. 6 for detailed locations).

The quartz fabrics measured from $\mathrm{XZ}$ sections are presented in lower hemisphere equal-area stereographic projection diagram (Fig. 10). In most of the samples of the Nanyue pluton, several point maxima develop. The maximum at a small angle $\left(10^{\circ}\right.$ to $25^{\circ}$ ) from the foliation pole ( $\mathrm{Z}$ axis) indicates the activity of the basal <a $>$ slip system (Figs. 10a-10e). Moreover, two other maxima are also measured. One is close to the center of the diagram ( $\mathrm{Y}$ axis, Figs. 10b and 10e), and another maximum at a small angle of the mineral lineation ( $\mathrm{X}$ axis, Figs. 10a-10e). This pattern suggests that prism $<\mathrm{a}\rangle$ and prism $<\mathrm{c}>$ slip systems were also activated, respectively. The opening angle between the $\mathrm{C}$-axis maxima ranges from $70^{\circ}$ to $100^{\circ}$, which corresponds to a deformation temperature of $600^{\circ} \mathrm{C}-700^{\circ} \mathrm{C}$ (Law, 2014). From a kinematic point of view, the asymmetric pattern of the $\mathrm{C}$-axis maxima is consistent with a top-to-the-NW sense of shear.

In the Baishifeng pluton, the c-axis patterns are more complex. In the gneissic zone, Samples HY 56 and SC274 (Figs. 10j and 10k) exhibit an oblique girdle or a maximum close to the $\mathrm{Z}$ and $\mathrm{Y}$ axes without any information of c-prism slide. The 
textural evidence of incipient dynamic recrystallization, illustrated by small-sized grains with serrated boundaries, is consistent with the post-solidus deformation they experienced. In the magmatic texture zone, samples HY67, HY74 and HY75 show a c-axis maximum close to the mineral lineation ( $\mathrm{X}$ axis) suggesting the activation of the prism <c> slip system (Figs. 10f, 10g and 10i). Moreover, Samples HY74 and HY75 also display c-axis maxima close to the $\mathrm{Y}$ axis and at a small angle of the $\mathrm{Z}$ axis likely indicating a combination of prism $<\mathrm{a}>$ and basal $<\mathrm{a}>$ slip systems (Figs. 10g and 10i). Sample HY54 is featured by a single $\mathrm{C}$-axis maximum close to $\mathrm{Y}$ axis indicating a prism <a> sliding (Fig. 10h). It should be noted that the strength of the clustering around $\mathrm{X}$ axis, hence the importance of prism $\langle\mathrm{c}\rangle$ slip increases eastwards (Figs. 10f-10k), i.e. away from the WHBF, where the Baishifeng pluton experienced a post-solidus deformation. The very large opening angle $\left(107^{\circ}\right)$ of Sample HY75 suggests a high temperature deformation of ca. $800^{\circ} \mathrm{C}$ (Law, 2014), in agreement with the texture of planar grain boundaries and a weak internal deformation in quartz. Such a fabric likely was developed in the magmatic state (i.e. in presence of melt). Except for Samples SC274 and HY56, located in the gneissic zone, other samples from the Baishifeng granite exhibit quartz texture with low or even absent dynamic recrystallization but high temperature deformation conditions.

\section{Gravity modeling}

Gravity modeling has been used to decipher the geometry of plutons at depth (e.g. Joly et al., 2009; Talbot et al., 2005b; Wei et al., 2014a). In this study, six NW-SE 
profiles and three NE-SW ones were constructed to establish the shape of the Hengshan massif. These profiles cover the entire massif and crosscut each others (Fig. 11). The Bouguer anomaly map is acquired from the Chinese 1:200,000 Bouguer anomaly database (offered by National Geologic Library of China).

\subsection{Bouguer regional and residual anomaly}

In the 1:200,000 Bouguer anomaly map of the Hengshan area as well as in the 1:500,000 Bouguer anomaly map with a larger regional extent, the Bouguer anomaly pattern around the Hengshan massif displays a clear NW-SE striking ribbon-like low value zone of long wavelength regional component. Before conducting a gravity modeling with the relatively short wavelength anomalies related to density contrasts between individual lithologies in the first kilometers of the crust, the long wavelength anomaly caused by the deep density contrasts should be removed. After several attempts, we used a low-pass Butterworth filter with a cutoff wavelength of $70 \mathrm{~km}$ on the 1:200,000 Bouguer anomaly map of the Hengshan area to acquire the long wavelength regional component. Then we subtracted this regional anomaly from the original 1:200,000 Bouguer anomaly to obtain a residual Bouguer map (Fig. 11).

In the residual Bouguer anomaly map, the negative and positive anomalies fit well with the granite and country rock contours and highest intensity anomalies correspond to the Proterozoic formations (Fig. 11). However, the Proterozoic sedimentary rocks do not have a very high density (Table 2). Considering that the Meso- and Neoproterozoic formations are the first sedimentary layers covering the Paleoproterozoic gneiss of the South China Block, it is reasonable to consider that the 
highest anomaly might be caused by the high density crystalline basement underlaid (Figs. $1 \mathrm{~b}$ and 11). We consider that this residual Bouguer anomaly map properly accounts for the structure of the upper crust and can be used to model the geometry of the plutons and country rocks.

In more detail, the contours of the residual Bouguer anomaly of the Hengshan massif show a more or less elliptical shape with a NE-SW long axis suggesting that the massif might have a constant thickness along this direction. It should be noted that the anomaly contour crosscuts the N-S boundary between the Baishifeng and Nanyue plutons. Considering their is a density contrast between these two plutons (Table 2), the contact surface between these two plutons should not be vertical at depth, otherwise the contour would be parallel to the lithologic boundary. The northeastern and southeastern boundaries between the Hengshan massif and the country rocks coincide with a high anomaly gradient suggesting a vertical contact between these two bodies. On the contrary, the western boundary of the massif coincides with a smooth gradient suggesting an oblique contact between these two geological bodies. In the eastern corner of the massif, the negative anomaly exceeds the boundary, indicating a continuity of the massif beneath the country rocks.

\subsection{Gravity profiles}

The boundaries of geological bodies, as well as the structure of country rocks of our model, are derived from the 1:200,000 geological map, and the thickness of the sedimentary layers is derived from the geological map notebook (HNBGMR, 1973). The densities of the main lithologies encountered in the study area were measured 
with the double weighting method (Table 2). In lacking specimens, the densities of two plutons (Hengxi1 and Hengxi2), which are located on the NW end of our profiles were calculated by Nettleton/Parasnis method (Hinze et al., 2012). Because the Ordovician and Cambrian rocks present similar lithology, in order to simplify the modeling, we use the same density and construct a single layer for the two periods. We also neglected the Permian, Triassic and Early Jurassic formations due to their thin thickness and narrow geographic distribution (Table 2). The density of the undifferentiated upper crust beneath the model should be chosen with care to avoid spurious effects in the modeling. According to the Crust 1.0 model (Laske et al., 2013), the undifferentiated upper crust corresponds to the upper crystalline basement $\left(2.72 \mathrm{~g} / \mathrm{cm}^{3}\right)$. Despite numerous attempts, the highest anomalies observed in the area could not be reproduced with the $2.72 \mathrm{~g} / \mathrm{cm}^{3}$ value of undifferentiated upper crust. Considering that the sediment cover density is underestimated by the crust 1.0 model (Table 2 and Appendix 1), the density of the middle crystalline basement of the Crust 1.0 model $\left(2.82 \mathrm{~g} / \mathrm{cm}^{3}\right)$ is used in this modeling. Given that the thickness of the Neoproterozoic sediments as basal cover of SCB is thin and widely outcrops in the study area (HNBGMR, 1987), the high density crystalline basement is shallowly buried here. The effects introduced by the choice of undifferentiated upper crust density on the gravity models will be discussed after conducting the profile gravity modeling. In order to avoid edge effects and to take into account the influence of the surrounding geological bodies around our target massif, our models extend several tens of kilometers into the country rocks. 
Six NW-SE profiles are constructed perpendicularly to the maximum elongation of the negative anomaly zone inside the massif, as well as to the strike of the WHBF and the Zhajiang basin (Profiles NW1 to NW6 in Fig. 11). Also, we constructed three NE-SW profiles (Profiles NE1 to NE3 in Fig. 11), perpendicular to the former, in order to better characterize the geometries at depth, and ascertain the models acquired by NW-SE profiles at the crossing points.

Our models reveal four noticeable features. Firstly, the Nanyue pluton is a very thin slice, ranging from 500 to $1000 \mathrm{~m}$, underlain by a 2 to $5 \mathrm{~km}$ thick Baishifeng two-mica pluton. Secondly, five out of the six NW-SE profiles reveal a variable thickness with a "sink" shape of the Baishifeng pluton. Only the NW1 profile, near the SW boundary of the Hengshan massif, where the massif is thinner than in the North, displays a flat base. Several "sinks" reaching a depth of 4-5 km are identified in each profile. Between these "sinks", the thickness of the granite is $2-3 \mathrm{~km}$ in average (Fig. 12). When considering all gravity profiles, the overall model of the granite suggests a laccolith-shaped upper part and a lower part formed by several “sinks”. When transferring these "sinks" onto the gravity map (Figs. 11 and 13), it can be noticed that they align in the NE-SW direction. Indeed, the overall shape of the massif appears to be controlled by a series of NE-SW elongated "sinking zones" parallel to profiles NE1, NE2 and NE3. Accordingly, in these three profiles, the massif displays little variations in thickness. Thirdly, the massif gravity model displays a box-like shape characterized by a flat roof and steep side walls. Finally, the Zhanjiang basin is a half-graben bounded by the NW dipping listric WHBF (Fig. 12). 
In order to evaluate the impact of errors on the choice of the undifferentiated upper crust density, we illustrate along Profile NW5, in Figure 12, the effects on the model geometry when we introduce $\pm 0.02 \mathrm{~g} / \mathrm{cm}^{3}$ variation in the undifferentiated upper crust density. Accordingly in some places, the granitic massif floor would vary about a maximum of $500 \mathrm{~m}$. But these variations do not significantly modify the overall shape of the model (Fig. 12).

The overall model agrees with the available geological and geophysical information. (1) The residual Bouguer gravity anomaly is well reproduced by the calculated effect of the model; (2) Thicknesses of the geological bodies are consistent in all NE-SW and the NW-SE profiles at their crossing points; (3) The folded and unconformity geometries considered in the model are consistent with the structures of country rocks provided by the geological map and our field observations.

\section{The monazite $\mathrm{U}-\mathrm{Th}-\mathrm{Pb}$ dating}

To determine the activity time of the WHBF, a gneissic two-mica granite sample "SC274" (location 5 in Fig. 1b) was analyzed for in-situ monazite U-Th-Pb chemical dating. After plating carbon coating, the thin section was observed by SEM in order to search monazite in the "Institut des Sciences de la Terre d'Orléans" (ISTO). In this sample, 24 monazite gains with size ranging from 5 to $30 \mu \mathrm{m}$ have been found. Under SEM, they are homogeneous with no zonation and automorphic in shape or with erosion harbor (Fig. 14a).

The monazite grains were analyzed with a Cameca SX 50 electron microprobe 
co-operated by ISTO and BRGM (Bureau de Recherches Géologiques et Minières) following the analytical procedure established by Cocherie et al. (1998). The analysis was conducted with $20 \mathrm{kV}$ acceleration voltage, $100 \mathrm{nA}$ beam current and with a 150 ppm for $\mathrm{U}$, Th and $\mathrm{Pb}$ absolute errors. Individual grain age and data sorting were realized by using EPMA/ex program written by Pommier et al. (2003). Owing to the low $\mathrm{Pb}$ content and small variation of $\mathrm{Th} / \mathrm{U}$ ratio, a representative isochron cannot be acquired using the $\mathrm{Th} / \mathrm{Pb}-\mathrm{U} / \mathrm{Pb}$ diagram (Cocherie and Albarede, 2001). The average monazite age was calculated at $106 \pm 4 \mathrm{Ma}$ (Fig. 14b) in the gneissic granite sample SC274. Result validity is given by comparison of theorical and calculated Mean Square Weight Deviation (MSWD) indicating a well constrained result (Fig. 14b).

\section{Discussion}

In order to understand the regional tectonic regime during the emplacement of the Hengshan massif, we have conducted a multidisciplinary study. In the following, we shall briefly summarize our observations and experiments, and then interpret their relationship and bearings on the regional tectonic regime.

\subsection{Summary of observations and experiments}

At the outcrop scale, the Nanyue biotite granite pluton exhibits well oriented K-feldspar megacrysts. Post-solidus gneissic fabrics develop only on the NW boundary of the Nanyue pluton and in the Zhurong peak (Location 2 and 3 in Fig. 1b), due to the influence of the intrusion of the Baishifeng pluton and the contemporaneous activity of the WHBF. Under the microscope, feldspar is broken 
into pieces, and quartz shows post-solidus ductile deformation. From east to west, the Baishifeng pluton shows a progressive deformation from preferred mineral orientation to gneissic, mylonitic and ultramylonitic textures. Macroscopic and microscopic observations and quartz $\mathrm{C}$-axis preferred orientation are consistent with a top-to-the-NW shear sense. The textural observations and the quartz c-axis fabrics are consistent with high temperature deformation mechanism for both plutons.

The magnetic susceptibility carriers of both Nanyue and Baishifeng plutons are paramagnetic (biotite and/or amphibole) making the magnetic fabrics parallel to the mineral fabrics and allowing its use for a direct structural analysis. The magnetic foliation of the Nanyue pluton gently dips to the southeast while its magnetic lineation concentrates in the NW-SE direction. Although the magnetic foliation of the Baishifeng pluton scatters, the magnetic lineation is better defined around the WNW-ESE direction.

The gravity models show that the Hengshan massif is box-shaped with a flat roof and vertical walls, and separated from the Zhajiang half-graben by the listric WHBF. The thin Nanyue pluton (500-1000 m) is underlain by the thick Baishifeng pluton (2-5 km) with a NE-SW elongated root and a "saw tooth-shaped" structure at its bottom.

\subsection{The origin of the magnetic fabric of the Hengshan composite granitic massif}

The primary magnetic fabrics acquired during the magma crystallization may record the magma flow direction or the regional tectonic regime during the pluton 
emplacement (e.g. Archanjo and Bouchez, 1997; Callot et al., 2001; De Oliveira et al., 2010; Neves et al., 2003; Talbot et al., 2005a; Turrillot et al., 2011; Wei et al., 2014b), while the secondary magnetic fabrics acquired after the full crystallization of the pluton reflects late tectonic events (e.g. Zhang and Zhu, 1989; Archanjo and Fetter, 2004; Charles et al., 2009). As a consequence, in order to understand the tectonic regime and its development time, we shall discuss the origin of the magnetic fabric.

In the magmatic texture zone of the Baishifeng pluton, although quartz experienced some ductile deformation and magnetic minerals might be rotated to some extent, such a texture took place under high temperature conditions during the process of magma consolidation. It should be also noted that the $\mathrm{P}_{\mathrm{J}}$ values from the magmatic texture zone of the Baishifeng pluton are usually lower than 1.2 (Fig. 5 and Table 1), indicating that fabric may well be coeval with magma crystallization as shown in many previous studies (e.g. Tarling and Hrouda, 1993). Thus the magnetic fabric of the magmatic texture zone is interpreted as a primary magnetic fabric coeval with the pluton emplacement. On the contrary, the $\mathrm{P}_{\mathrm{J}}$ values of the samples from the gneissic zone of the pluton are usually higher than 1.2 which is consistent with the deformation observed in the outcrops. It is concluded that the magnetic fabric in the gneissic granite zone is secondary due to deformation.

The situation of the Nanyue pluton seems to be more complex with its $\mathrm{P}_{\mathrm{J}}$ values lower than 1.2 even for the gneissic samples. In the outcrop scale, feldspar and biotite orientations have been observed without obvious solid state deformation. However, under the microscope, broken feldspars and ductile deformation features in 
quartz and biotite commonly develop, consistent with a post-solidus deformation (see Sections 5.2 and 5.3). In this situation, the biotite and amphibole can hardly resist rotation to form a secondary magnetic fabric. It should be noted that this kind of deformation also developed at high temperature as revealed by quartz microtexture and "Open Angle" of the c-axis maxima point. Several possibilities for the acquisition time of the magnetic fabrics of the Nanyue biotite granite can be considered. Namely, 1) during or soon after the emplacement of the Nanyue pluton in which the high temperature was maintained by the residue heat of the Nanyue pluton itself; 2) after the full crystallization of the Nanyue pluton, during a high temperature regional ductile shearing; or 3) during a regional ductile shearing coeval with the emplacement of the Baishifeng pluton, in which the high temperature was caused by the thermal effect of the crystallizing Baishifeng two-mica granite. For the first possibility, the lack of coeval regional ductile shear zone weakens this possibility. For the second possibility, the unmetamorphic or very low degree metamorphic country rocks do not support the regional high temperature event. The last possibility is recommended due to the following reasons. The heat responsible for the high temperature deformation can be easily produced by the emplacement of the young Baishifeng pluton, as indicated by the gravity modeling, a thin Nanyue pluton is underlain by a thick Baishifeng pluton. The observed deformation is due to the activity of the WHBF as discussed in Section 8.3, the WHBF is coeval with the emplacement of the Baishifeng pluton. 


\subsection{Time relationship between the development of the WHBF and the emplacement of the Baishifeng pluton}

When a ductile fault develops along the boundary of a pluton, the activity of the fault could be coeval or not with the emplacement of the pluton. In the first case, the fault plays an important role in the emplacement of the pluton. The pluton is considered as syn-tectonic. The Gudaoling pluton in the Liaoning peninsula and the Guojialing pluton in the Jiaodong peninsula belong to this category (Charles et al., 2010 and 2012). In the second case, the fault may have played a role in the exhumation of the already crystallized pluton. There is no relationship between the fault activity and the pluton emplacement. The Yiwulushan pluton in the south Liaoning belongs to this category (Lin et al., 2013a and b).

The Nanyue and Baishifeng plutons yield zircon $\mathrm{U}-\mathrm{Pb}$ isotopic ages at $230 \pm 2 \mathrm{Ma}$ and $150 \pm 1 \mathrm{Ma}$, respectively. The activity period of the WHBF was estimated from $136 \mathrm{Ma}$ to $97 \mathrm{Ma}$ on the basis of zircon $\mathrm{U}-\mathrm{Pb}$ and mica ${ }^{40} \mathrm{Ar} /{ }^{39} \mathrm{Ar}$ ages of the deformed albitite (Li et al., 2013). Thus neither the Nanyue nor the Baishifeng pluton were regarded as syn-tectonic bodies ( $\mathrm{Li}$ et al., 2013). However, the albitite is a metasomatic product in the tectonites of the shear zone related to fluid circulation (Xiao, 1989; Li et al., 2013). This U-Pb isotopic age represents the crystallization age of zircon formed from a fluid phase, which is younger than the beginning of the fault activity. For the same reason, our $106 \pm 4$ Ma EPMA monazite age is also interpreted as the result of fluid activity along the already active shear zone. During our survey, the frequently observed tourmalines in the WHBF also favor an important fluid 
circulation during or after the ductile shearing (Fig. 2e).

According to several structural observations, we argue that the initiation of the WHBF and the emplacement of the Baishifeng pluton were contemporaneous.

Both the field and microscopic observations show that the deformation degree of the Baishifeng pluton increases from the east to the west, and reaches its climax in the WHBF on the boundary between the pluton and the Zhajiang Basin (Fig. 15). The consistency among the magnetic foliation, magmatic foliation, schlieren orientation in the magmatic texture zone of the Baishifeng pluton with the ductile deformation fabric in the gneissic and mylonitic zones favor a syntectonic interpretation for the Baishifeng pluton.

In addition, our gravity modeling reveals that the magmatic texture zone crops out in the center of the Baishifeng pluton. The quartz c-axis fabric in this zone indicates a high temperature deformation $\left(700-800^{\circ} \mathrm{C}\right)$ illustrated by dominantly prism $<\mathrm{c}>$, and prism $<\mathrm{a}>$ with subordinate basal $<\mathrm{a}>$ slip (Fig. 10). In contrast, in the gneissic granite zone and the mylonitic zone that develops on the western boundary of the pluton, deformation in quartz was accommodated by prism $\langle\mathrm{a}\rangle$ and basal $\langle\mathrm{a}\rangle$ gliding, indicating a medium deformation temperature at $400^{\circ}-550^{\circ} \mathrm{C}$ by our and previous estimation (Figs 10j and 10k; Li et al., 2013). Such a high temperature condition in the center of the pluton suggests a deformation coeval with pluton crystallization (e.g. Duguet and Faure, 2004; Liotta et al., 2008; Menegon et al., 2008; Festa, 2009), and the westward decrease of prism $\langle\mathrm{c}\rangle$ gliding mechanism likely resulted from a faster cooling rate on the pluton boundary than in its center during the 
emplacement.

Hence the good consistency between the mineral and magnetic fabrics, and the shear sense observed among all samples from the Nanyue pluton and the Baishifeng pluton (magmatic texture zone and gneissic zone) as well as the WHBF may be considered as a consequence of the shearing along the WHBF during the emplacement of the Baishifeng pluton (Fig. 15).

\subsection{Emplacement and exhumation mode of the Baishifeng pluton}

Previous studies showed that the WHBF is a low angle detachment fault with at least $10 \mathrm{~km}$ dip-slip displacement (Xu et al., 1998). The augen gneiss of the gneissic granite zone of the Baishifeng two-mica pluton was considered as an augen migmatite standing for the deep crust material (Wang, 1990b). Thus the Hengshan massif was regarded as a Metamorphic Core Complex in which the WHBF was active during the emplacement of the massif (Xu et al., 1998; Zhang, 1994a). However, due to lack of the nebulitic structures of the migmatite, such as mesosomes and leucosomes (e.g. Vernon and Collins, 1988; Brown, 2001) in the gneiss zone of the Baishifeng pluton, it is more reasonable to consider the augen gneiss as the product of a ductile shearing of the two-mica granite. Furthermore, in agreement with some previous studies our observations show that the Neoproterozoic sedimentary country rocks were involved in the low degree metamorphism, and cannot stand for lower crust materials (e.g. HNBGMR, 1987). Thus, the hypothesis of the WHBF with large distance displacement and the Hengshan massif MCC still needs further evidence. At least, the absence of significant metamorphism in the footwall does not support this hypothesis. 
Some scholars emphasized the passive vertical intrusion of the Baishifeng two-mica pluton noticing that there is no obvious horizontal shortening in the country rocks due to the effect of pluton emplacement (e.g. Zhang, 1992). In this hypothesis, the WHBF, as well as the gneissic biotite granite in the Zhurong peak on the boundary between the two plutons were interpreted as the products of relative movement caused by the ascent of the Baishifeng pluton (Zhang, 1992). However, the top-to-the-NW shear sense found in the Zhurong peak does not support this hypothesis (Figs. 9b, 10b-10f).

Other scholars emphasized the important role played by WHBF in the exhumation of the Hengshan massif. It was noticed that a west-younging trend of the $\mathrm{Ar}^{40}-\mathrm{Ar}^{39}$ cooling ages of the detachment of the western part of the Hengshan massif (WHBF and the gneissic zone in this paper), which may imply a hotter (deeper) western part of the detachment than the eastern part. Thus the hypothesis of eastward titling with $26-50^{\circ}$ of the detachment as well the whole Hengshan massif along the WHBF during the exhumation was proposed ( $\mathrm{Li}$ et al., in press). However, when interpreting the $\mathrm{Ar}^{40}-\mathrm{Ar}^{39}$ data within a ductile detachment, it should be cautioned with the possibility of chronometer reset by polyphase thermal fluid recycling as suggested by the zircon age of $136 \mathrm{Ma}$ and the monazite age of $106 \mathrm{Ma}$ acquired in the detachment (Figs. 2e and 14b; Xiao, 1989; Zhang, 1994b; Li et al., 2013). So the younger cooling age in the western part of this detachment cannot be simply correlated with a deeper ancient burial depth. This trend may just reflect that the fluid activity ceased later in WHBF than in that in the gneissic granite zone. Besides, a 
normal posture of the Hengshan massif with vertical roots illustrated by our gravity modeling do not support such a large amplitude of tilting neither.

As discussed above, the magnetic fabrics from the Baishifeng pluton were acquired during the emplacement. Along the boundary between the Baishifeng and Nanyue plutons, the strike of the magnetic foliation of the Baishifeng pluton is parallel to the contour of the boundary and dips to the outer side. This phenomenon suggests a vertical magma injection. Meanwhile, the strike of the magnetic foliation of the Nanyue pluton is usually perpendicular to the boundary without records of any structural reworking due to the emplacement of the Baishifeng pluton. Moreover, as the gravity modeling shows, the Baishifeng pluton is featured by a 'sawtooth'-shaped root structure. Considering the non- or low degree metamorphism of the country rocks, it is reasonable to suggest that the Baishifeng pluton intrudes into a shallow depth where tension gash can be opened to accommodate the magma injection. The pluton roots represent tension gashes. It means that the emplacement of the Baishifeng pluton is permissive rather than forceful and a "box-like" shape of the pluton with a flat roof, and vertical side walls also favor to this interpretation (Pitcher, 1979).

\subsection{Regional tectonic regime during the emplacement of the Baishifeng two-mica}

\section{granitic pluton}

During the emplacement, a well-grouped magnetic lineation usually indicates a regional extension regime and its direction is parallel to the extensional direction (e.g. Talbot et al., 2000 and 2005a; Joly et al., 2007 and 2009; Turrillot et al., 2011). In this 
study, the primary magnetic lineation of the Baishifeng pluton strikes WNW-ESE direction, indicating that this region was under the control of a NW-SE extensional regime at about $150 \mathrm{Ma}$. Besides, the three NE-SW oriented roots, representing tension-gashes of the Baishifeng pluton also argue for a NW-SE extensional regime.

The WHBF activity fits well to the emplacement of the Baishifeng pluton and the formation of the NE-SW trended Zhajiang basin. As revealed by the field observation and gravity modeling, the Zhajiang basin is a half-graben basin. The oldest sediments infilled in this basin are of the Early Cretaceous, a little bit younger than the Baishifeng pluton (HNBGMR, 1987). The top-to-the-NW sense of shear along the boundary fault complies with a normal fault. The elongation of the contemporaneous Zhajiang basin and the WHBF also favor a NW-SE extension during the Late Jurassic - Cretaceous.

In summary, a NW-SE extensional tectonic regime, starting in the Late Jurassic and lasting the whole Cretaceous, characterizes well the syn-emplacement structure of the Baishifeng two-mica pluton, the activity of the WHBF, and the formation of the Zhajiang half-graben.

\section{Conclusions}

Aiming to clarify the debate on the tectonic regime in South China at the Late Jurassic, the Hengshan Massif that comprises the Nanyue and Baishifeng plutons dated at 230 and $150 \mathrm{Ma}$, respectively, has been investigated by a multidisciplinary approach. The following conclusions can be drawn. 
1. Field observations and the microstructural analyses on the thin sections reveal a high temperature deformation in the Nanyue pluton and the eastern part of the Baishifeng pluton, the deformation temperature decreases westwards in the Baishfieng pluton. The ductile deformation in the Hengshan massif shows a consistent top-to-the-NW shear sense. Magnetic fabric measurements present a consistent NW-SE lineation with weakly inclined foliation.

2. Gravity modeling reveals a laccolith shaped massif with a well-defined NE-SW oriented 'sawtooth-shaped' pluton root. These NE-SW linear structures may be considered as indicative of tension-gashes that accommodated the Baishifeng pluton emplacement.

3. Integrating previous geological and geochronological results into our new observations, an extensional tectonic regime in the Late Jurassic may be reliably established for the study area by the coeval emplacement of the syntectonic Baishifeng pluton, the Western Hengshan Massif Fault and the half-graben Zhajiang basin.

The emplacement of the Hengshan massif provides an example of the Late Jurassic extensional event that occurred in the central part of the South China Block.

\section{Acknowledgments}

This study was funded by NSFC (41225009), the grant of Ministry of Land and Resources (201211024-04), NSFC (41502215), NSFC (41472193) and Grant No. 2011ZX05008-001. We present our sincere thanks to Prof. J-L Bouchez and another 
anonymous reviewer for their constructive suggestions and detail reviews.

\section{References}

Archanjo, C.J., Bouchez, J.L., 1997. Magnetic fabrics and microstructures of the post-collisional aegirine-augite syenite Triunfo pluton, northeast Brazil. Journal of Structural Geology 19, 849-860.

Archanjo, C.J., Fetter, A.H., 2004. Emplacement setting of the granite sheeted pluton of Esperanca (Brasiliano orogen, Northeastern Brazil). Precambrian Research $135,193-215$.

Aurejac, J.B., Gleizes, G.R., Diot, H., Bouchez, J.L., 2004. The Quérigut Complex (Pyrenees, France) revisited by the AMS technique: a syntectonic pluton of the Variscan dextral transpression. Bulletin de la Société Géologique de France 175, $157-174$.

Bouchez, J.L., Gleizes, G., 1995. 2-stage deformation of the Mont-Louis-Andorra granite pluton (Variscan Pyrenees) inferred from magnetic-susceptibility anisotropy. Journal of the Geological Society 152, 669-679.

Brown, H., 2001. Orogeny, migmatites and leucogranites: A review. Proceedings of the Indian Academy of Sciences-Earth and Planetary Sciences 110, 313-336.

Callot, J.P., Geoffroy, L., Aubourg, C., Pozzi, J.P., Mege, D., 2001. Magma flow directions of shallow dykes from the East Greenland volcanic margin inferred from magnetic fabric studies. Tectonophysics 335, 313-329.

Charles, N., Faure, M., Chen, Y., 2009. The Montagne Noire migmatitic dome 
emplacement (French Massif Central): new insights from petrofabric and AMS studies. Journal of Structural Geology 31, 1423-1440.

Charles, N., Gumiaux, C., Augier, R., Chen, Y., Zhu, R., Lin, W., 2010. Metamorphic Core Complexes vs. synkinematic plutons in continental extension setting: Insights from key structures (Shandong Province, eastern China). Journal of Asian Earth Sciences.

Charles, N., Gumiaux, C., Augier, R., Chen, Y., Faure, M., Lin, W., Zhu, R., 2012. Metamorphic Core Complex dynamics and structural development: Field evidences from the Liaodong Peninsula (China, East Asia). Tectonophysics $560-561,22-50$.

Charvet, J., Shu, L.S., Shi, Y.S., Guo, L.Z., Faure, M., 1996. The building of south China: Collision of Yangzi and Cathaysia blocks, problems and tentative answers. Journal of Southeast Asian Earth Sciences 13, 223-235.

Chu, Y., Faure, M., Lin, W., Wang, Q., 2012. Early Mesozoic tectonics of the South China block: Insights from the Xuefengshan intracontinental orogen. Journal of Asian Earth Sciences 61, 199-220.

Cocherie, A., Albarede, F., 2001. An improved U-Th-Pb age calculation for electron microprobe dating of monazite. Geochimica et Cosmochimica Acta 65, 4509-4522.

Cocherie, A., Legendre, O., Peucat, J., Kouamelan, A., 1998. Geochronology of polygenetic monazites constrained by in situ electron microprobe Th-U-total lead determination: implications for lead behaviour in monazite. Geochimica et 
Cosmochimica Acta 62, 2475-2497.

Dash, B., Yin, A., Jiang, N., Tseveendorj, B., Han, B., 2015. Petrology, structural setting, timing, and geochemistry of Cretaceous volcanic rocks in eastern Mongolia: Constraints on their tectonic origin. Gondwana Res 27, 281-299.

Davis, G.A., Darby, B.J., 2010. Early Cretaceous overprinting of the Mesozoic Daqing Shan fold-and-thrust belt by the Hohhot metamorphic core complex, Inner Mongolia, China. Geoscience Frontiers 1, 1-20.

De Oliveira, D.C., Neves, S.P., Trindade, R.I.F., Dall'Agnol, R., Mariano, G., Correia, P.B., 2010. Magnetic anisotropy of the Redencao granite, eastern Amazonian craton (Brazil): Implications for the emplacement of A-type plutons. Tectonophysics 493, 27-41.

Duguet, M., Faure, M., 2004. Granitoid emplacement during a thrusting event: structural analysis, microstructure and quartz c-axis patterns. An example from Hercynian plutons in the French Massif Central. Journal of Structural Geology 26, 927-945.

Faure M., 1995, Late orogenic Carboniferous extensions in the Variscan French Massif Central. Tectonics 14, 132-153.

Faure, M., Lin, W., Scharer, U., Shu, L.S., Sun, Y., Arnaud, N., 2003. Continental subduction and exhumation of UHP rocks. Structural and geochronological insights from the Dabieshan (East China). Lithos 70, 213-241.

Faure, M., Lin, W., Sun, Y., 1998. Doming in the southern foreland of the Dabieshan (Yangtse block, China). Terra Nova 10, 307-311. 
Faure, M., Shu, L.S., Wang, B., Charvet, J., Choulet, F., Monié, P., 2009. Intracontinental subduction: a possible mechanism for the Early Palaeozoic Orogen of SE China. Terra Nova 21, 360-368.

Faure, M., Lepvrier, C., Nguyen, V.V., Vu, T.V., Lin, W., Chen, Z., 2014. The South China block-Indochina collision: Where, when, and how? Journal of Asian Earth Sciences 79, Part A, 260-274.

Faure, M., W. Lin, Y. Chu, Lepvrier, C., Triassic tectonics of the Southern margin of the South China Block, Comptes Rendus Geoscience, in press.

Ferre, E.C., Gebelin, A., Till, J.L., Sassier, C., Burmeister, K.C., 2014. Deformation and magnetic fabrics in ductile shear zones: A review. Tectonophysics 629, 179-188.

Festa, V., 2009. C-axis fabrics of quartz-ribbons during high-temperature deformation of syn-tectonic granitoids (Sila Massif, Calabria, Italy). Comptes Rendus Geoscience 341, 557-567.

Ge, T.M., Liu, J., Fan, L.M., Zhong, S.X., Wu, N.Y., Vindell, H., Baksi, A., 1994. Magnetostratigraphy of the Red beds in Hengyang Basin. Acta Geologica Sinica 68, 379-388.

Gilder, S.A., Gill, J., Coe, R.S., Zhao, X.X., Liu, Z.W., Wang, G.X., Yuan, K.R., Liu, W.L., Kuang, G.D., Wu, H.R., 1996. Isotopic and paleomagnetic constraints on the Mesozoic tectonic evolution of south China. Journal of Geophysical Research-Solid Earth 101, 16137-16154.

Gilder, S.A., Keller, G.R., Luo, M., Goodell, P., 1991. Eastern Asia and the western 
Pacific timing and spatial distribution of rifting in China. Tectonophysics 197, 225-243.

Goodell, P.C., Gilder, S., Fang, X., 1991. A preliminary description of the Gan-Hang failed rift, southeastern China. Tectonophysics 197, 245-255.

Hinze, W.J., Von Frese, R.R.B., Saad, A.H., 2012. Gravity and Magnetic Exploration: Principles, Practices, and Applications, 1 ed. Cambridge University Press, New York.

HNBGMR, 1987. Regional geology of Hunan province. Geological Publishing House, Beijing.

HNBGMR, t.t.r.g.i.t.o., 1973. 1:200000 regional geological investigation report in Hengyang area. Geological Publishing House, Beijing.

Jiao, W.F., Wu, Y.B., Yang, S.H., Peng, M., Wang, J., 2009. The oldest basement rock in the Yangtze Craton revealed by zircon $\mathrm{U}-\mathrm{Pb}$ age and $\mathrm{Hf}$ isotope composition. Science China D 52, 1393 - 1399.

Jelinek, V., 1981. Characterization of the magnetic fabric of rocks. Tectonophysics 79, T63-T67.

Joly, A., Chen, Y., Faure, M., Martelet, G., 2007. A multidisciplinary study of a syntectonic pluton close to a major lithospheric-scale fault - Relationships between the Montmarault granitic massif and the Sillon Houiller Fault in the Variscan French Massif Central: 1. Geochronology, mineral fabrics, and tectonic implications. Journal of Geophysical Research-Solid Earth 112.

Joly, A., Faure, M., Martelet, G., Chen, Y., 2009. Gravity inversion, AMS and 
geochronological investigations of syntectonic granitic plutons in the southern part of the Variscan French Massif Central. Journal of Structural Geology 31, 421-443.

JXBGMR, 1984. Regional geology of Jiangxi province. Geological Publishing House, Beijing.

Laske, G., Masters, G., Ma, Z., Pasyanos, M., 2013. Update on CRUST1.0 - A 1-degree Global Model of Earth's Crust, EGU General Assembly Conference Abstracts.

Law, R.D., 2014. Deformation thermometry based on quartz c-axis fabrics and recrystallization microstructures: A review. Journal of Structural Geology 66, 129-161.

Li, J., Shi, W., Zhang, Y., Dong, S., Ma, Z., Thermal evolution of the Hengshan extensional dome in central South China and its tectonic implications: New insights into low-angle detachment formation. Gondwana Research. in press.

Li, J., Zhang, Y., Dong, S., Li, H., 2012a. Late Mesozoic-Early Cenozoic deformation history of the Yuanma Basin, central South China. Tectonophysics.

Li, J.H., Zhang, Y.Q., Dong, S.W., Su, J.b., Li, Y., Cui, J.J., Shi, W., 2013. The Hengshan low-angle normal fault zone: structural and geochronological constraints on the Late Mesozoic crustal extension in South China. Tectonophysics 606, 97-115.

Li, J.W., Zhou, M.F., Li, X.F., Fu, Z.R., Li, Z.J., 2001. The Hunan-Jiangxi strike-slip fault system in southern China: southern termination of the Tan-Lu fault. J 
Geodyn 32, 333-354.

Li, S., Zhao, G., Zhang, G., Liu, X., Dong, S., Wang, Y., Liu, X., Suo, Y., Dai, L., Jin, C., 2010b. Not all folds and thrusts in the Yangtze foreland thrust belt are related to the Dabie Orogen: Insights from Mesozoic deformation south of the Yangtze River. Geological Journal 45, 650-663.

Li, S.Z., Santosh, M., Zhao, G.C., Zhang, G.W., Jin, C., 2012b. Intracontinental deformation in a frontier of super-convergence: A perspective on the tectonic milieu of the South China Block. Journal of Asian Earth Sciences 49, 313-329.

Li, X.-H., Li, W.-X., Li, Z.-X., Lo, C.-H., Wang, J., Ye, M.-F., Yang, Y.-H., 2009. Amalgamation between the Yangtze and Cathaysia Blocks in South China: constraints from SHRIMP U-Pb zircon ages, geochemistry and $\mathrm{Nd}-\mathrm{Hf}$ isotopes of the Shuangxiwu volcanic rocks. Precambrian Res 174, 117-128.

Li, X., Zhou, G., Zhao, J., Fanning, C., Compston, W., 1994. SHRIMP ion microprobe zircon $\mathrm{U}-\mathrm{Pb}$ age and $\mathrm{Sm}-\mathrm{Nd}$ isotopic characteristics of the NE Jiangxi ophiolite and its tectonic implications. Chinese Journal of Geochemistry 13, 317-325.

Li, X.H., Li, W.X., Wang, X.C., Li, Q.L., Liu, Y., Tang, G.Q., Gao, Y.Y., Wu, F.Y., 2010a. SIMS U-Pb zircon geochronology of porphyry $\mathrm{Cu}-\mathrm{Au}-(\mathrm{Mo})$ deposits in the Yangtze River Metallogenic Belt, eastern China: Magmatic response to early Cretaceous lithospheric extension. Lithos 119, 427-438.

Li, Z.X., Li, X.H., 2007. Formation of the 1300-km-wide intracontinental orogen and postorogenic magmatic province in Mesozoic South China: A flat-slab subduction model. Geology 35, 179-182. 
Lin, W., Faure, M., Monie, P., Scharer, U., Zhang, L.S., Sun, Y., 2000. Tectonics of SE China: New insights from the Lushan massif (Jiangxi Province). Tectonics 19, $852-871$.

Lin, W., Faure, M., Chen, Y., Wenbin Ji a, Wang, F., Wu, L., Charles, N., Wang, J., and Wang, Q., 2013a, Late Mesozoic compressional to extensional tectonics in the Yiwulüshan massif, NE China and its bearing on the evolution of the Yinshan-Yanshan orogenic belt Part I: Structural analyses and geochronological constraints: Gondwana Research 2013a, 54-77.

Lin, W., Charles, N., Chen, Y., Chen, K., Faure, M., Wu, L., Wang, F., Li, Q.L., Wang, J., and Wang, Q.C., 2013b, Late Mesozoic compressional to extensional tectonics in the Yiwulushan massif, NE China and their bearing on the Yinshan-Yanshan orogenic belt Part II: Anisotropy of magnetic susceptibility and gravity modeling: Gondwana Research, v. 23, p. 78-94.

Lin, W., Ji, W., Faure, M., Lin W., Li, Q., Shi, Y., Schaerer, U., Wang, F., Wang, Q., 2015, Early Cretaceous extensional reworking of the Triassic HP-UHP metamorphic orogen in Eastern China: Tectonophysics 662, 256-270.

Liotta, D., Caggianelli, A., Kruhl, J.H., Festa, V., Prosser, G., Langone, A., 2008. Multiple injections of magmas along a Hercynian mid-crustal shear zone (Sila Massif, Calabria, Italy). Journal of Structural Geology 30, 1202-1217.

Mao, J., Xie, G., Duan, C., Pirajno, F., Ishiyama, D., Chen, Y., 2011. A tectono-genetic model for porphyry-skarn-stratabound $\mathrm{Cu}-\mathrm{Au}-\mathrm{Mo}-\mathrm{Fe}$ and magnetite-apatite deposits along the Middle-Lower Yangtze River Valley, Eastern China. Ore Geol 
Rev 43, 294-314.

Mattauer, M., Matte, P., Malavieille, J., Tapponnier, P., Maluski, H., Xu, Z.Q., Lu, Y.L., Tang, Y.Q., 1985. Tectonics of the Qinling belt - buildup and evolution of eastern Asia. Nature 317, 496-500.

Menegon, L., Pennacchioni, G., Heilbronner, R., Pittarello, L., 2008. Evolution of quartz microstructure and c-axis crystallographic preferred orientation within ductilely deformed granitoids (Arolla unit, Western Alps). Journal of Structural Geology 30, 1332-1347.

Meng, Q.-R., 2003. What drove late Mesozoic extension of the northern China-Mongolia tract? Tectonophysics 369, 155-174.

Mercier, J.L., Hou, M.J., Vergely, P., Wang, Y.M., 2007. Structural and stratigraphical constraints on the kinematics history of the southern Tan-Lu fault zone during the Mesozoic Anhui Province, China. Tectonophysics 439, 33-66.

Neves, S.P., Araujo, A.M.B., Correira, P.B., Mariano, G., 2003. Magnetic fabrics in the Cabanas Granite (NE Brazil): interplay between emplacement and regional fabrics in a dextral transpressive regime. Journal of Structural Geology 25, 441-453.

Pitcher, W.S., 1979. The nature, ascent and emplacement of granitic magmas. Journal of the Geological Society 136, 627-662.

Pommier, A., Cocherie, A., Legendre, O., 2003. EPMA dating: a program for age calculation from electron microprobe measurements of U-Th-Pb, EGU2003.

Qiu, Y., Gao, S., 2000. First evidence of > 3.2 Ga continental crust in the Yangtze 
craton of South China and its implications for Archean crustal evolution and Phanerozoic tectonics. Geology 28, 11-14.

Ren, J.Y., Tamaki, K., Li, S.T., Junxia, Z., 2002. Late Mesozoic and Cenozoic rifting and its dynamic setting in Eastern China and adjacent areas. Tectonophysics 344, 175-205.

Shu, L.S., Faure, M., Jiang, S.Y., Yang, Q., Wang, Y.J., 2006. SHRIMP zircon U-Pb age, litho- and biostratigraphic analyses of the Huaiyu Domain in South China Evidence for a Neoproterozoic orogen, not Late Paleozoic-Early Mesozoic collision. Episodes 29, 244-252.

Shu, L.S., Zhou, X.M., Deng, P., Wang, B., Jiang, S.Y., Yu, J.H., Zhao, X.X., 2009. Mesozoic tectonic evolution of the Southeast China Block: New insights from basin analysis. Journal of Asian Earth Sciences 34, 376-391.

Shu, L.S., Zhou, X.M., Deng, P., Zhu, W.B., 2007. Mesozoic-Cenozoic Basin features and evolution of Southeast China. Acta Geologica Sinica-English Edition 81, 573-586.

Shu, L.S., Faure, M., Yu, J.H., Jahn, B.M., 2011. Geochronological and geochemical features of the Cathaysia block (South China): New evidence for the Neoproterozoic breakup of Rodinia. Precambrian Research. 187, 263-276.

Stipp, M., Stünitz, H., Heilbronner, R., Schmid, S.M., 2002. The eastern Tonale fault zone: a 'natural laboratory' for crystal plastic deformation of quartz over a temperature range from 250 to $700^{\circ} \mathrm{C}$. Journal of Structural Geology 24, 1861-1884. 
Talbot, J.Y., Chen, Y., Faure, M., 2005a. A magnetic fabric study of the Aigoual-Saint Guiral-Liron granite pluton (French Massif Central) and relationships with its associated dikes. Journal of Geophysical Research-Solid Earth 110.

Talbot, J.Y., Chen, Y., Faure, M., Lin, W., 2000. AMS study of the Pont-de-Montvert-Borne porphyritic granite pluton (French Massif Central) and its tectonic implications. Geophysical Journal International 140, 677-686.

Talbot, J.Y., Faure, M., Chen, Y., Martelet, G., 2005b. Pull-apart emplacement of the Margeride granitic complex (French Massif Central). Implications for the late evolution of the Variscan orogen. Journal of Structural Geology 27, 1610-1629.

Tarling, D.H., Hrouda, F., 1993. The magnetic anisotropy of rocks. Chapman \& Hall, London.

Turrillot, P., Faure, M., Martelet, G., Chen, Y., Augier, R., 2011. Pluton-dyke relationships in a Variscan granitic complex from AMS and gravity modelling. Inception of the extensional tectonics in the South Armorican Domain (France). Journal of Structural Geology 33, 1681-1698.

Vernon, R.H., Collins, W.J., 1988. Igneous microstructures in migmatites. geology 16, 1126-1129.

Wang, F., Zhou, X.-H., Zhang, L.-C., Ying, J.-F., Zhang, Y.-T., Wu, F.-Y., Zhu, R.-X., 2006. Late Mesozoic volcanism in the Great Xing'an Range (NE China): Timing and implications for the dynamic setting of NE Asia. Earth Planet Sc Lett 251, 179-198.

Wang, J.B., 1990a. Discussion on some problems about Jiepai migmatite belt in the 
western margin of Hengshan mountain. Hunan Geology 9, 39-50.

Wang, J.B., 1990b. Diwa-type granite of Hengshan: origin by fractural melting. Geotectonica et Metallogenia 14, 247-254.

Wang, J., and Li, Z.X., 2003, History of Neoproterozoic rift basins in South China: implications for Rodinia break-up: Precambrian Research 122, 141-158.

Wang, T., Guo, L., Zhang, L., Yang, Q., Zhang, J., Tong, Y., Ye, K., 2015. Timing and evolution of Jurassic-Cretaceous granitoid magmatisms in the Mongol-Okhotsk belt and adjacent areas, NE Asia: Implications for transition from contractional crustal thickening to extensional thinning and geodynamic settings. Journal of Asian Earth Sciences 97, Part B, 365-392.

Wang, Y., Fan, W., Zhang, G., Zhang, Y., 2013. Phanerozoic tectonics of the South China Block: key observations and controversies. Gondwana Research 23, 1273-1305.

Wei, W., Martelet, G., Le Breton, N., Shi, Y., Faure, M., Chen, Y., Hou, Q., Lin, W., Wang, Q., 2014a. A multidisciplinary study of the emplacement mechanism of the Qingyang-Jiuhua massif in Southeast China and its tectonic bearings. Part II: Amphibole geobarometry and gravity modeling. Journal of Asian Earth Sciences 86, 94-105.

Wei, W., Chen, Y., Faure, M., Shi, Y.H., Martelet, G., Hou, Q.L., Lin, W., Le Breton, N., Wang, Q.C., 2014b. A multidisciplinary study on the emplacement mechanism of the Qingyang-Jiuhua Massif in Southeast China and its tectonic bearings. Part I: Structural geology, AMS and paleomagnetism. Journal of Asian 
Earth Sciences 86, 76-93.

Wei, W., Faure, M., Chen, Y., Ji, W., Lin, W., Wang, Q., Yan, Q., Hou, Q., 2015. Back-thrusting response of continental collision: Early Cretaceous NW-directed thrusting in the Changle-Nan'ao belt (Southeast China). Journal of Asian Earth Sciences 100, 98-114.

Wu, F.-Y., Lin, J.-Q., Wilde, S.A., Zhang, X.O., Yang, J.-H., 2005. Nature and significance of the Early Cretaceous giant igneous event in eastern China. Earth and Planet Science Letters 233, 103-119.

Xiao, D.H., 1989. Geology and metallogenetic pattern of Maji albite deposit, Hengshan county. Hunan Geology 8, 29-34.

Xu, H., Fu, W., Xu, J., 1998. The deformation feature and strain analysis of the Jiepai dip-slip ductile shear zone in Hengshan mountain. Hunan Geology 17, 85-90.

Xu, J., Zhu, G., Tong, W., Cui, K., Liu, Q., 1987. Formation and evolution of the Tancheng-Lujiang wrench fault system: a major shear system to the northwest of the Pacific Ocean. Tectonophysics 134, 273-310.

Yan, D.P., Zhou, M.F., Song, H.L., Wang, X.W., Malpas, J., 2003. Origin and tectonic significance of a Mesozoic multi-layer over-thrust system within the Yangtze Block (South China). Tectonophysics 361, 239-254.

Yu, J., O'Reilly, Y.S., Wang, L.S., Griffin, W.L., Jiang, S., Wang, Y.J., Xu, X., 2007. Finding of ancient materials in Cathaysia and implication for the formation of Precambrian crust. Chinese Science Bulletin 52, 11 - 18.

Yu, J.H., Wang, L.J., Griffin, W.L., O'Reilly, S.Y., Zhang, M., Li, C.Z., Shu, L.S., 
2009. A Paleoproterozoic orogeny recorded in a long-lived cratonic remnant (Wuyishan terrane), eastern Cathaysia Block, China. Precambrian Research $174,347-363$.

Yu, J.H., O'Reilly, S.Y., Wang, L.J., Griffin, W.L., Zhou, M.F., Zhang, M., Shu, L.S., 2010. Components and episodic growth of Precambrian crust in the Cathaysia Block, south China: evidence from $\mathrm{U}-\mathrm{Pb}$ ages and $\mathrm{Hf}$ isotopes of zircons in Neoproterozoic sediments. Precambrian Research 181, 97 - 114.

Zhang, J.-H., Ge, W.-C., Wu, F.-Y., Wilde, S.A., Yang, J.-H., Liu, X.-M., 2008. Large-scale Early Cretaceous volcanic events in the northern Great Xing'an Range, northeastern China. Lithos 102, 138-157.

Zhang, J., 1994a. Tectonic feature of the western edge in the metamorphic nucleus complex of Hengshan. Journal of East China Geological Institute 17, 18-22.

Zhang, J., 1994b. On denudational fault and its control over Uranium metallogenesis at the western margin of Hengshan metamorphic core complex. Uranium Geology 10, 144-185.

Zhang, Y., Xu, X., Jia, D., 2009. Deformation record of the change from Indosinian collision-related tectonic system to Yanshanian subduction-related tectonic system in South China during the Early Mesozoic. Earth Science Frontiers 16, 234-247.

Zhang, Z., 1992. Characterristics, genesis and emplacement mechanism of the ductile shear zone along western margin of Hengshan granite. Hunan Geology 11, 198-202. 
Zhang, Z., Zhu, Z., 1989. Comparing Study of the Magnetic Fabric with the Deformation Fabric of the Western Margin Ductile Shear Zone of Hengshan Composite Granite. Journal of Shijiazhuang University of Economics 12, 313-324.

Zhou, X.M., Li, W.X., 2000. Origin of Late Mesozoic igneous rocks in Southeastern China: implications for lithosphere subduction and underplating of mafic magmas. Tectonophysics 326, 269-287.

Zhou, X.M., Sun, T., Shen, W.Z., Shu, L.S., Niu, Y.L., 2006. Petrogenesis of Mesozoic granitoids and volcanic rocks in South China: A response to tectonic evolution. Episodes 29, 26-33.

Zhou, Y.-Z., Han, B.-F., Zhang, B., Xu, Z., Ren, R., Li, X.-W., Su, L., 2012. The Yingba shear zone on the Sino-Mongolian border: Southwestern extension of the Zuunbayan Fault from Mongolia to China and implications for Late Mesozoic intracontinental extension in Eastern Asia. Tectonophysics 574, 118-132.

Zhu, G., Niu, M.L., Xie, C.L., Wang, Y.S., 2010. Sinistral to Normal Faulting along the Tan-Lu Fault Zone: Evidence for Geodynamic Switching of the East China Continental Margin. Journal of Geology 118, 277-293.

\section{Table and figure captions}

Table 1 The results of AMS measurements of the Hengshan granitic massif

Site: sampling site, Lat: Latitude, long: Longitude, Lith: Lithology, Km: average susceptibility, $\mathrm{P}_{\mathrm{J}}$ : Susceptibility anisotropy degree, T: The shape parameter of the AMS ellipsoid, $\mathrm{K}_{1}$ : Magnetic lineation, $\mathrm{K}_{3}$ :The pole of the magnetic foliation, Inc: 
Inclination, Dec: Declination, $\alpha_{95} \max$ and $\alpha_{95} \mathrm{~min}$ : The long and short axis of the confidence ellipsoid at 95\% level, BG: Biotite granite, TMG: Two-mica granite.

Table 2 Rock densities and the thickness of the strata involved in the gravity modeling in the study area

The figures of densities which are in bold is calculated by Nettleton/Parasnis method (Hinze et al., 2012), the rest densities are calculated by double weighting method. The thickness of the strata refer to (HNBGMR, 1973).

Figure 1. Simplified geological map of the Hengshan area. Q: Quaternary sand and silt, E: Eocene sandstone, K: Cretaceous conglomerate and sandstone, J: Jurassic sandstone and siltstone, P: Permian shale and chert, C: Carboniferous limestone, D: Devonian sandstone and siltstone, Pt: Proterozoic sandstone and slate, I: Magmatic texture zone, II: gneissic zone, III and WHBF: West Hengshan Boundary Fault. The grey dash line is the boundary between the gneissic granite zone and granite with oriented mineral zone. AA': Geological cross section of Figure 15. Xiu-Yong Fault in Fig. 1a: Xiushui-Yongzhou fault.

Figure 2. Field observations on the Hengshan composite granitic massif (locations in Fig. 1b). a: NW-SE preferred orientation of K-feldspar in the Nanyue pluton (Location 1); b: Magmatic foliation developed in the eastern part of the Baishifeng pluton (Location 4); 
c: Gneissic foliation developed in the western part of the Baishifeng pluton, "sigmoid" quartz indicates the top-to-the-NW shear sense (Location 5); d: inclined fold of ultramylonite indicating a top-to-the-NW shear sense (Location 6); e: cracked dark tourmaline indicating thermal fluid activity during development of the shear zone (near Location 6); f: Cataclasite formed by brecciation of ultramylonite (near Location 6); g: Cracked pebbles in the Cretaceous Zhajiang basin close to the shear zone (Location 6); h: Exposure of the shear zone showing the succession from the ultra-mylonite of two-mica granite, cataclasite, and brecciated conglomerate from SE to NW, respectively (Location 6); i: Sigmoidal quartz vein in the Neoproterozoic strata indicating a top-to-the-NW shear sense (Location 7); j: Sandstone strata of the Zhajiang basin tilted to the SE near the shear zone, indicating a normal shear sense (on the pluton-massif boundary near Location 5 with a bedding of $50^{\circ}$ dip angle).

Figure 3. Histogram of bulk magnetic susceptibility of the Hengshan composite granitic massif.

Figure 4. Hysteresis loop diagrams of the Hengshan composite granitic massif.

Figure 5. AMS scalar parameters of each site and main lithologies of the Hengshan composite granitic massif. a: $\mathrm{P}_{\mathrm{J}}$ (corrected anisotropy degree) vs. Km (mean bulk magnetic susceptibility in $10^{-6} \mathrm{SI}$ ), b: $\mathrm{T}$ (shape parameter) vs. $\mathrm{P}_{\mathrm{J}}$. The calculation formulas of $\mathrm{T}$ and $\mathrm{P}_{\mathrm{J}}$ can be found in Jelinek (1981). 
Figure 6. Equal-area lower hemisphere projection of AMS results of each site from the Hengshan massif. Squares and circles stand for $\mathrm{K}_{1}$ (magnetic lineation) and $\mathrm{K}_{3}$ (pole of magnetic foliation), respectively. Small and large grey squares or circles represent individual specimen and site-mean direction with their confidence ellipses at 95\% level, respectively. The sites marked by a letter in a grey circle are the sites of the quartz C-axis measurements presented in Figure 10. The stereographic projections highlighted with dash circle are with inconsistent magnetic lineation, please refer Section 4.3 in the text.

Figure 7. Equal-area lower hemisphere projection of total magnetic fabric of the Hengshan massif. In this diagram, each square and circle represent average value of $\mathrm{K}_{1}$ (magnetic lineation) and $\mathrm{K}_{3}$ (magnetic foliation pole) for one site.

Figure 8. Map of magnetic fabric distribution of the Hengshan composite granitic massif.

Figure 9. Microscopic observation on the Hengshan massif. Pictures a to $\mathrm{c}$ are from the Nanyue pluton, and d to i from the Baishifeng pluton. All thin sections are located in fig. $1 b$.

a: Cataclased K-Feldspar (Location 9); b: Sigmoidal biotite and feldspar, indicating a top-to-the-NW shear sense (Location 2); c: Mechanical twins indicating a 
post-solidus deformation developed in feldspar (Location 12); d: Magmatic texture (Location 4); e: Subgrains and wavy extinction of quartz indicating a slight magmatic deformation in the central part of the pluton (Location 10); f: Sigmoidal shape of muscovite indicating a top-to-the-NW shear sense in the western part of the pluton (Location 5); g: Mica fish structure in the western part of the pluton indicating a top-to-the-NW shear sense (Location 11), h: Bookshelf structure in feldspar of ultramylonite indicating a top-to-the-NW shear sense (Location 6), i: Sigmoidal muscovite of ultramylonite along the southwestern boundary of the Baishifeng pluton indicating a top-to-the-NW shear sense (Location 8).

Figure 10. Quartz C-axis fabrics measured by universal stage (N: number or measurements) and quartz texture of the Hengshan composite granitic massif. OA: opening angle between the quartz C-axis maxima. Refer to Figure 6 for the sample detailed locations and the comparison between $\mathrm{C}$-axis preferred orientation and the magnetic fabric.

Figure 11. Residual Bouguer anomaly map of the Hengshan composite massif and its surrounding area with location of the modeled gravity profiles shown in Fig. 12.

Figure 12. Forward gravity modeling conducted along 6 NW-SE profiles and 3 NE-SW profiles across the Hengshan composite granitic massif (see Fig. 11 for profile locations). 
Figure 13. 3D shape of the Hengshan composite massif.

Figure 14. Monazite $\mathrm{U}-\mathrm{Th}-\mathrm{Pb}$ chemical dating of the Baishifeng two-mica pluton involved in the West Hengshan shear zone.

Figure 15. Cross section through the Hengshan composite massif and its country rocks (location shown in Fig. 1b). 

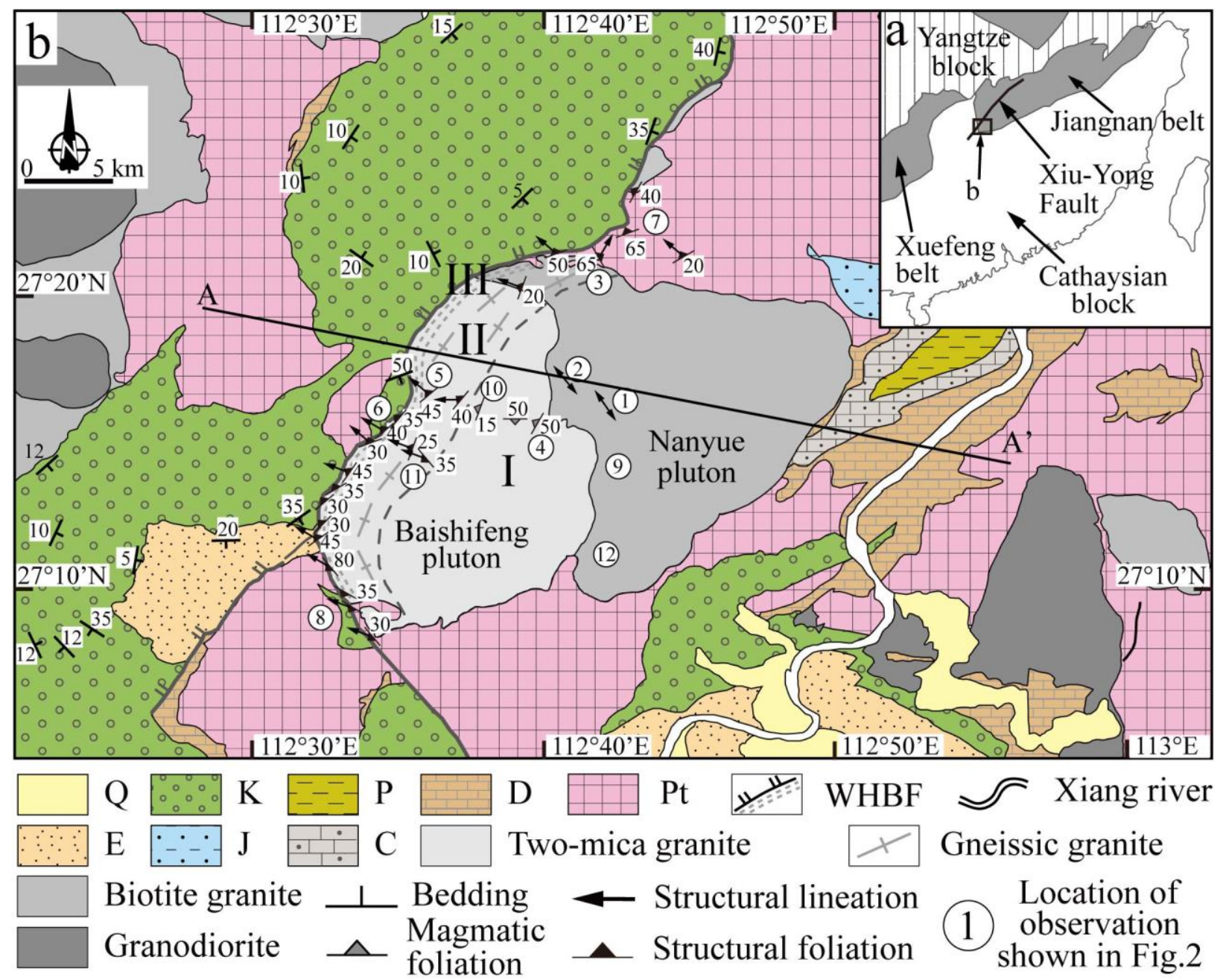

Figure 1. Simplified geological map of the Hengshan area. Q: Quaternary sand and

silt, E: Eocene sandstone, K: Cretaceous conglomerate and sandstone, J: Jurassic

sandstone and siltstone, P: Permian shale and chert, C: Carboniferous limestone, D:

Devonian sandstone and siltstone, Pt: Proterozoic sandstone and slate, I: Magmatic

texture zone, II: gneissic zone, III and WHBF: West Hengshan Boundary Fault. The

grey dash line is the boundary between the gneissic granite zone and granite with

oriented mineral zone. AA': Geological cross section of Figure 15. Xiu-Yong Fault in

Fig. 1a: Xiushui-Yongzhou fault. 


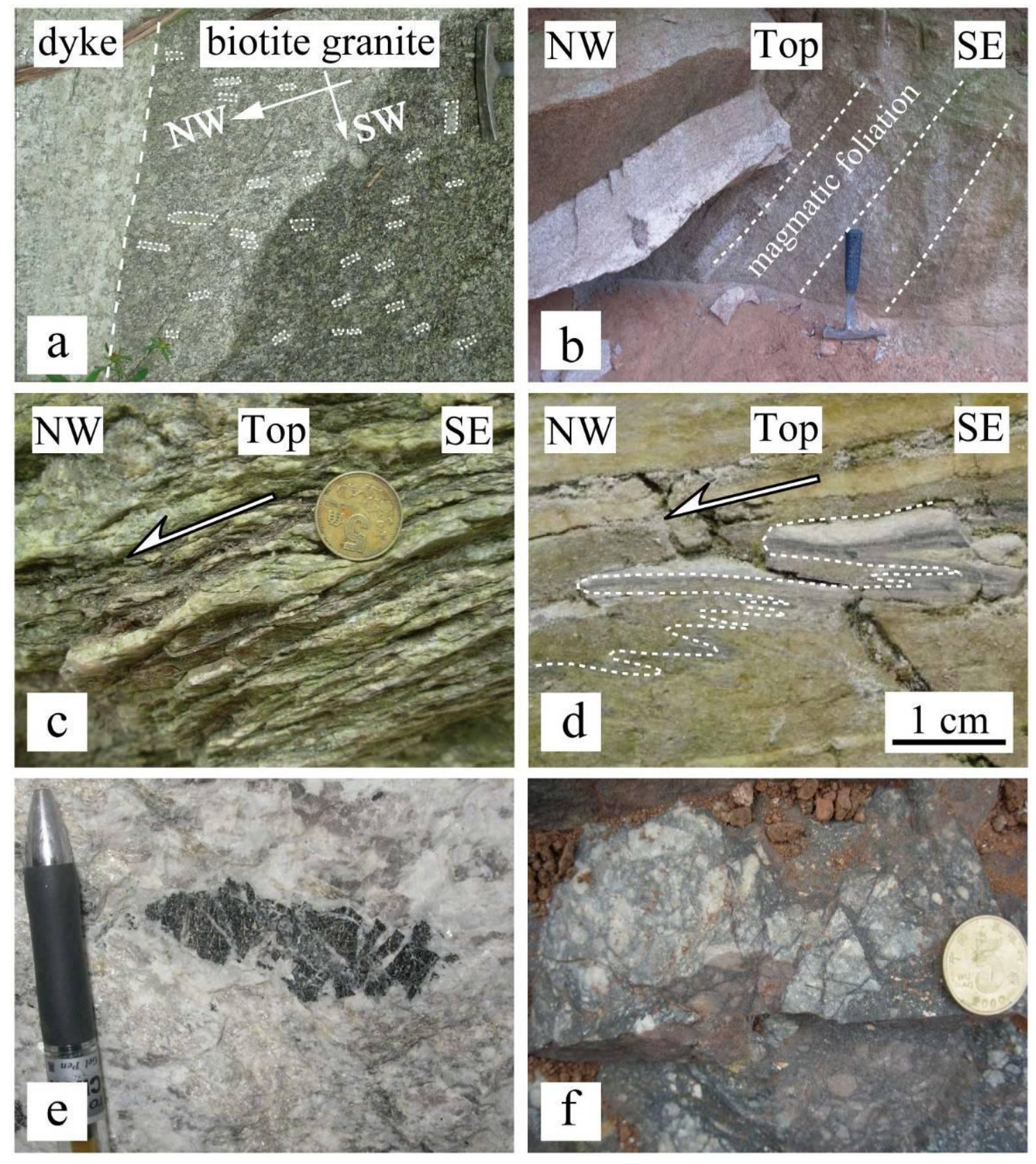



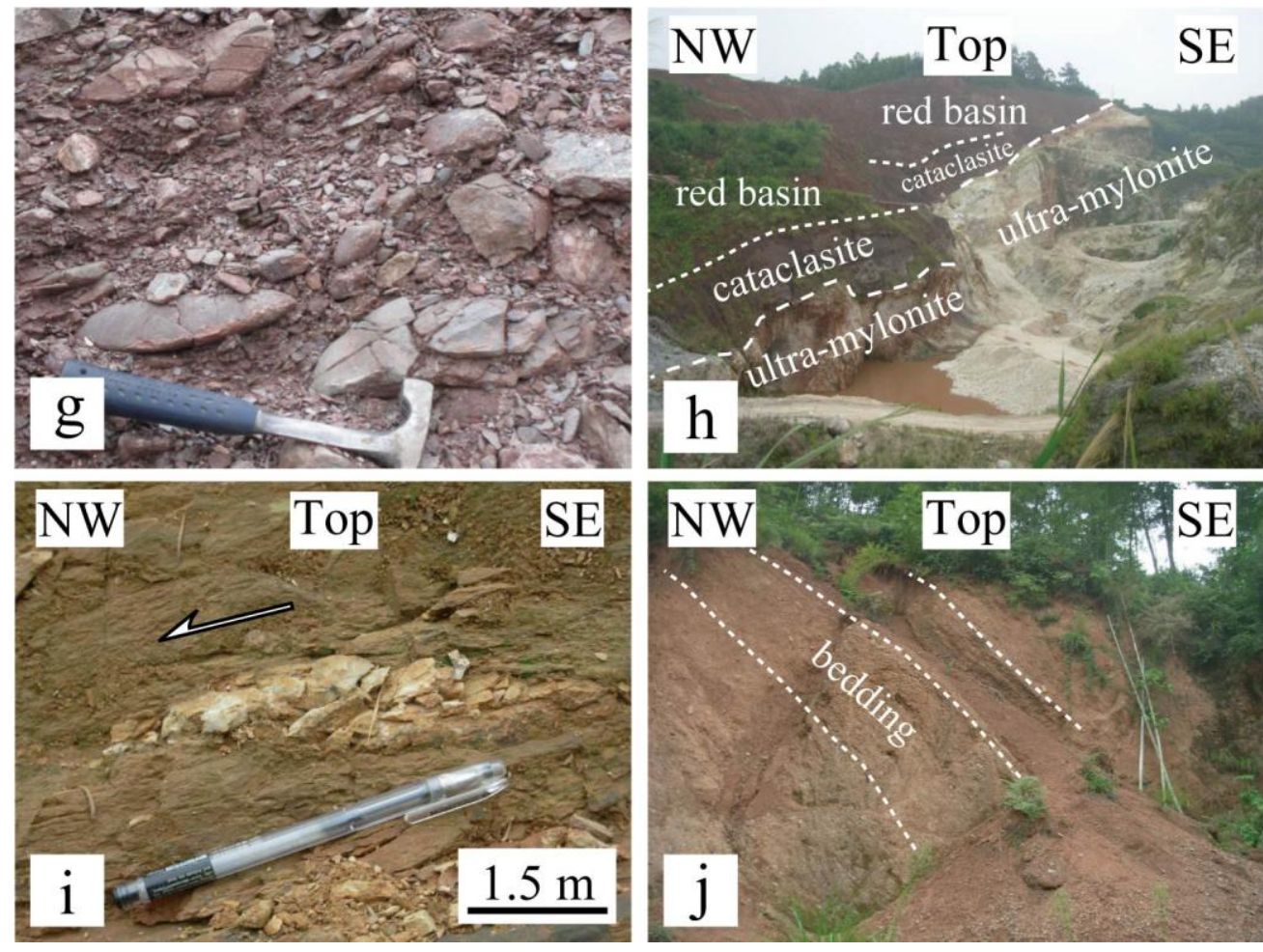

Figure 2. Field observations on the Hengshan composite granitic massif (locations in

Fig. 1b).

a: NW-SE preferred orientation of K-feldspar in the Nanyue pluton (Location 1); b:

Magmatic foliation developed in the eastern part of the Baishifeng pluton (Location 4);

c: Gneissic foliation developed in the western part of the Baishifeng pluton, "sigmoid" quartz indicates the top-to-the-NW shear sense (Location 5); d: inclined fold of ultramylonite indicating a top-to-the-NW shear sense (Location 6); e: cracked dark tourmaline indicating thermal fluid activity during development of the shear zone (near Location 6); f: Cataclasite formed by brecciation of ultramylonite (near Location 6); g: Cracked pebbles in the Cretaceous Zhajiang basin close to the shear zone (Location 6); h: Exposure of the shear zone showing the succession from the ultra-mylonite of two-mica granite, cataclasite, and brecciated conglomerate from SE to NW, respectively (Location 6); i: Sigmoidal quartz vein in the Neoproterozoic 
strata indicating a top-to-the-NW shear sense (Location 7); j: Sandstone strata of the Zhajiang basin tilted to the SE near the shear zone, indicating a normal shear sense (on the pluton-massif boundary near Location 5 with a bedding of $50^{\circ}$ dip angle). 


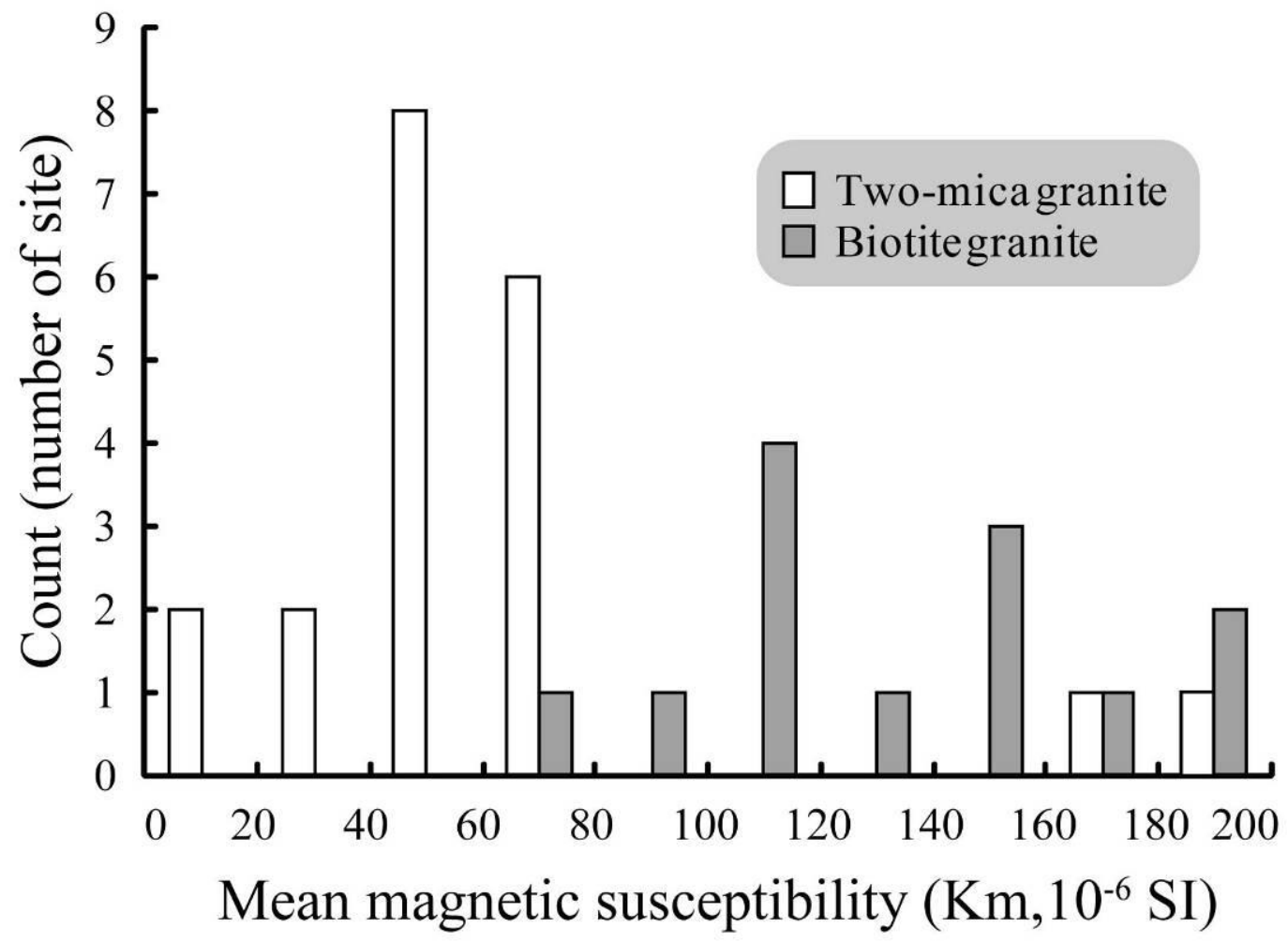

Figure 3. Histogram of bulk magnetic susceptibility of the Hengshan composite granitic massif. 
a

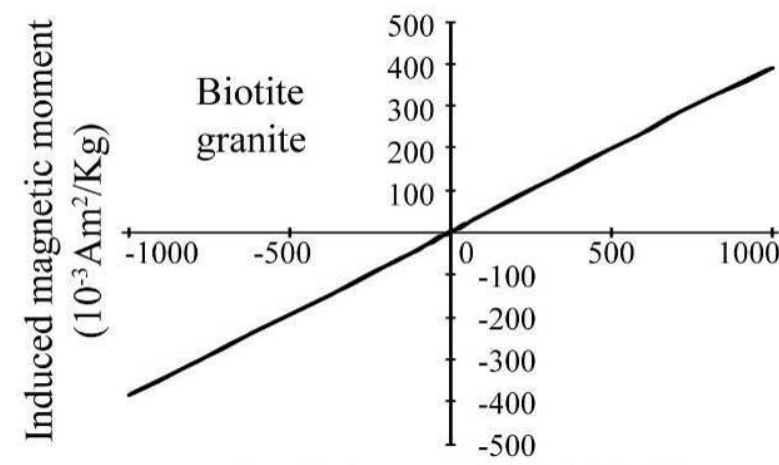

Applied magnetic field (mT) b HY54

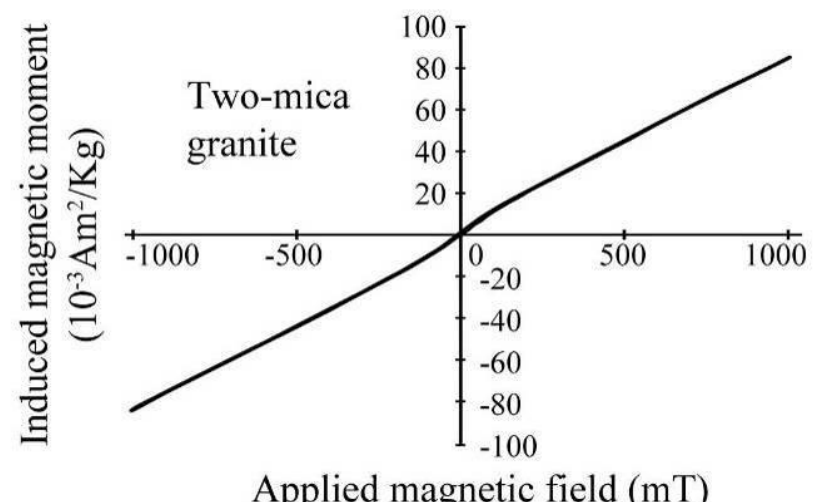

Applied magnetic field (mT)

Figure 4. Hysteresis loop diagrams of the Hengshan composite granitic massif. 


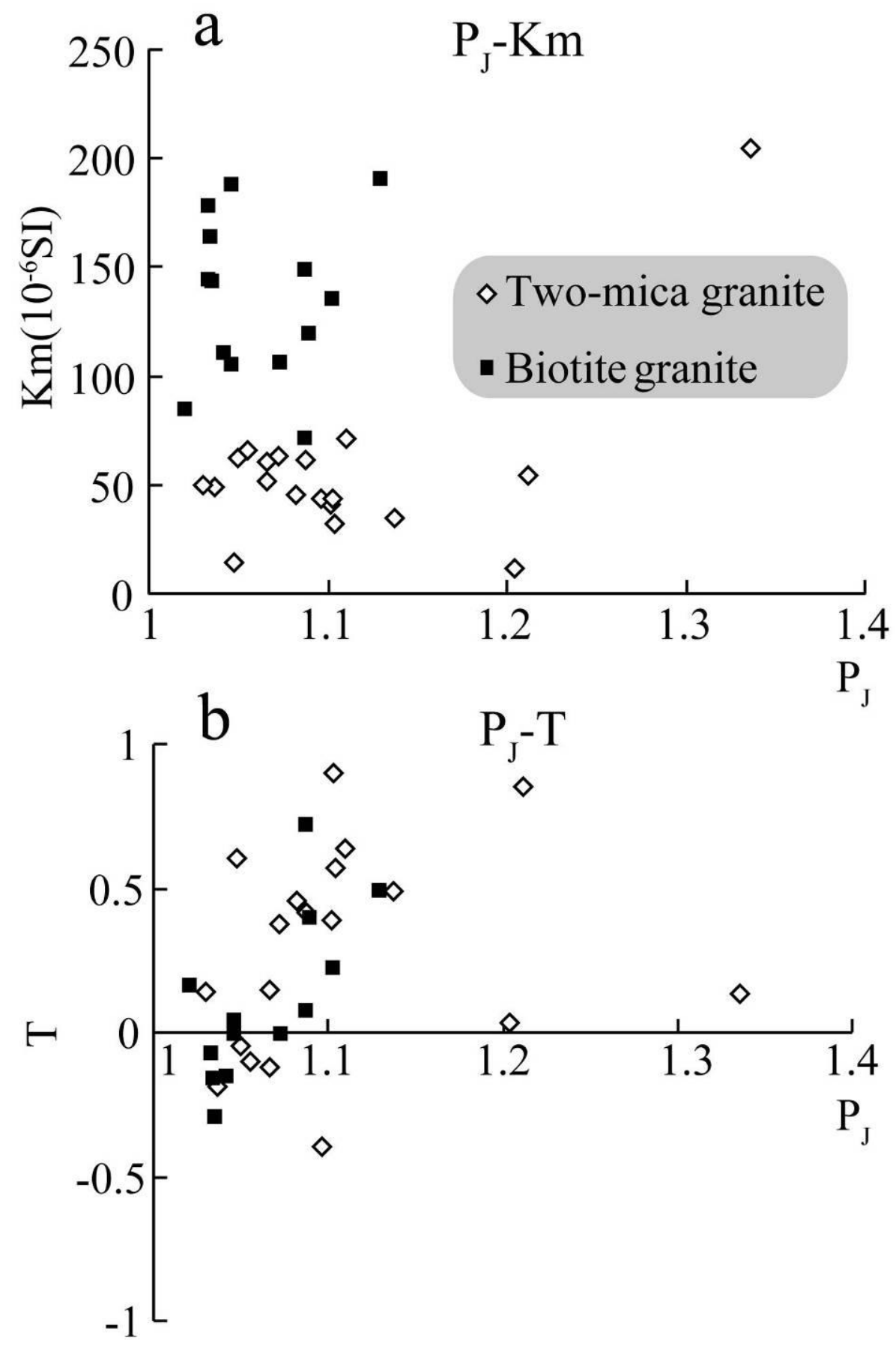

Figure 5. AMS scalar parameters of each site and main lithologies of the Hengshan composite granitic massif. a: $\mathrm{P}_{\mathrm{J}}$ (corrected anisotropy degree) vs. Km (mean bulk magnetic susceptibility in $10^{-6} \mathrm{SI}$ ), b: $\mathrm{T}$ (shape parameter) vs. $\mathrm{P}_{\mathrm{J}}$. The calculation formulas of $\mathrm{T}$ and $\mathrm{P}_{\mathrm{J}}$ can be found in Jelinek (1981). 


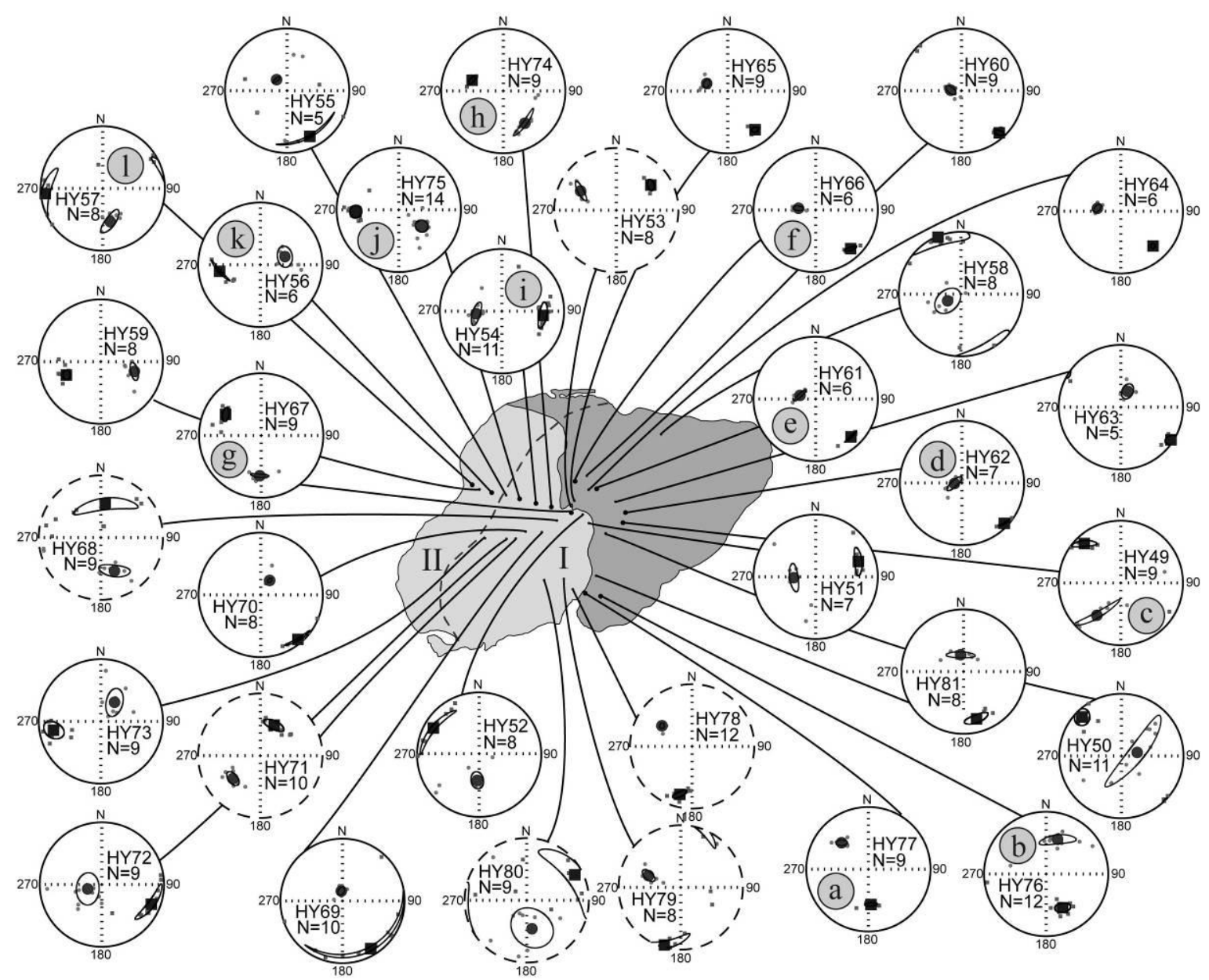

Two-mica granite of the Baishifeng granite

$\mathrm{K}_{1}$ (magnetic lineation) of each sample Site average of $\mathrm{K}_{1}$ with its confidence ellipsoid Biotite granite of the Nanyue granite $\cdot \cdot{ }_{\text {of each sample }}^{\mathrm{K}}$ (magnetic foliation pole)

Figure 6. Equal-area lower hemisphere projection of AMS results of each site from the Hengshan massif. Squares and circles stand for $\mathrm{K}_{1}$ (magnetic lineation) and $\mathrm{K}_{3}$ (pole of magnetic foliation), respectively. Small and large grey squares or circles represent individual specimen and site-mean direction with their confidence ellipses at 95\% level, respectively. The sites marked by a letter in a grey circle are the sites of the quartz C-axis measurements presented in Figure 10. The stereographic projections highlighted with dash circle are with inconsistent magnetic lineation, please refer Section 4.3 in the text. 

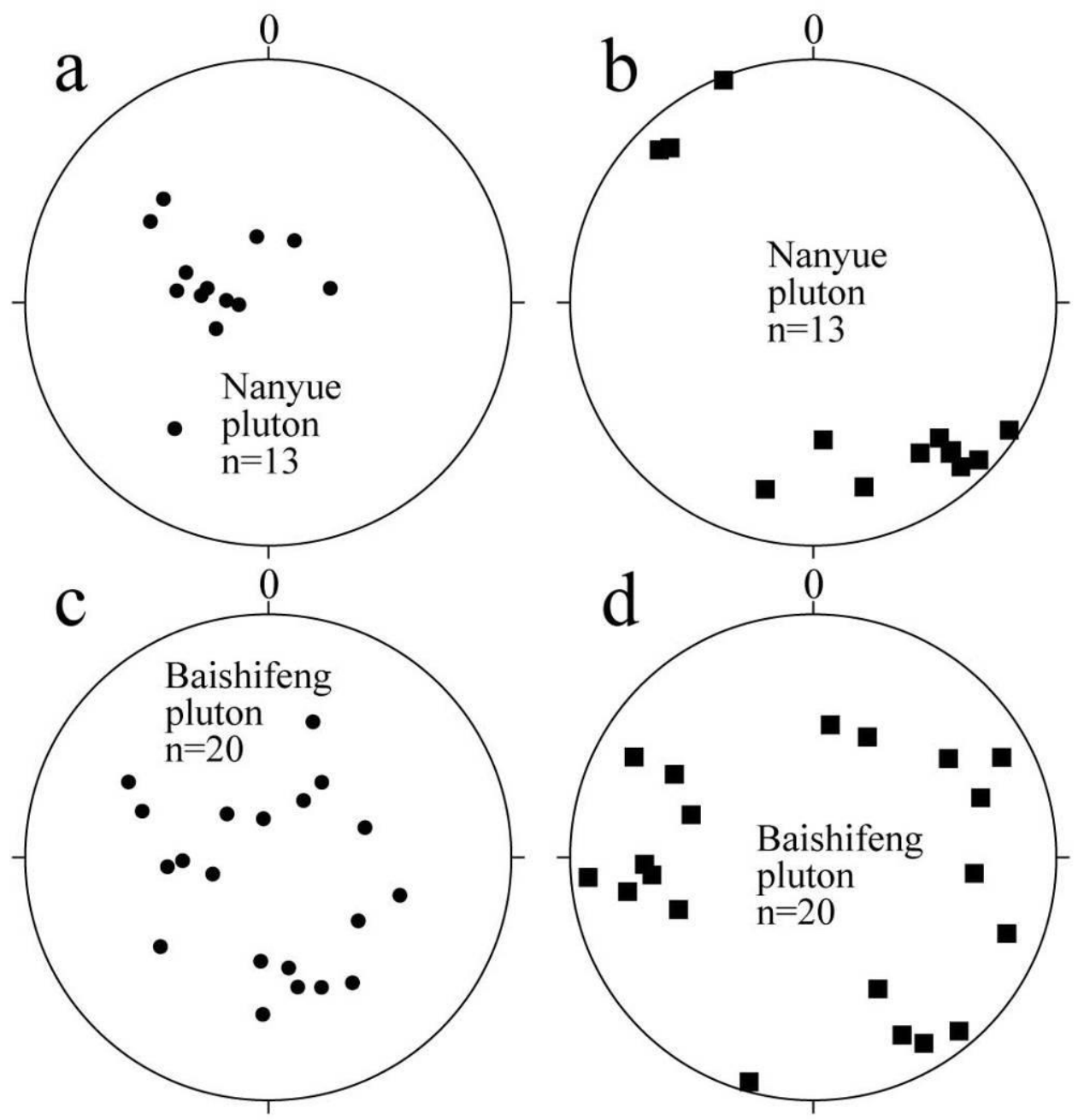

Figure 7. Equal-area lower hemisphere projection of total magnetic fabric of the

Hengshan massif. In this diagram, each square and circle represent average value of $\mathrm{K}_{1}$ (magnetic lineation) and $\mathrm{K}_{3}$ (magnetic foliation pole) for one site. 


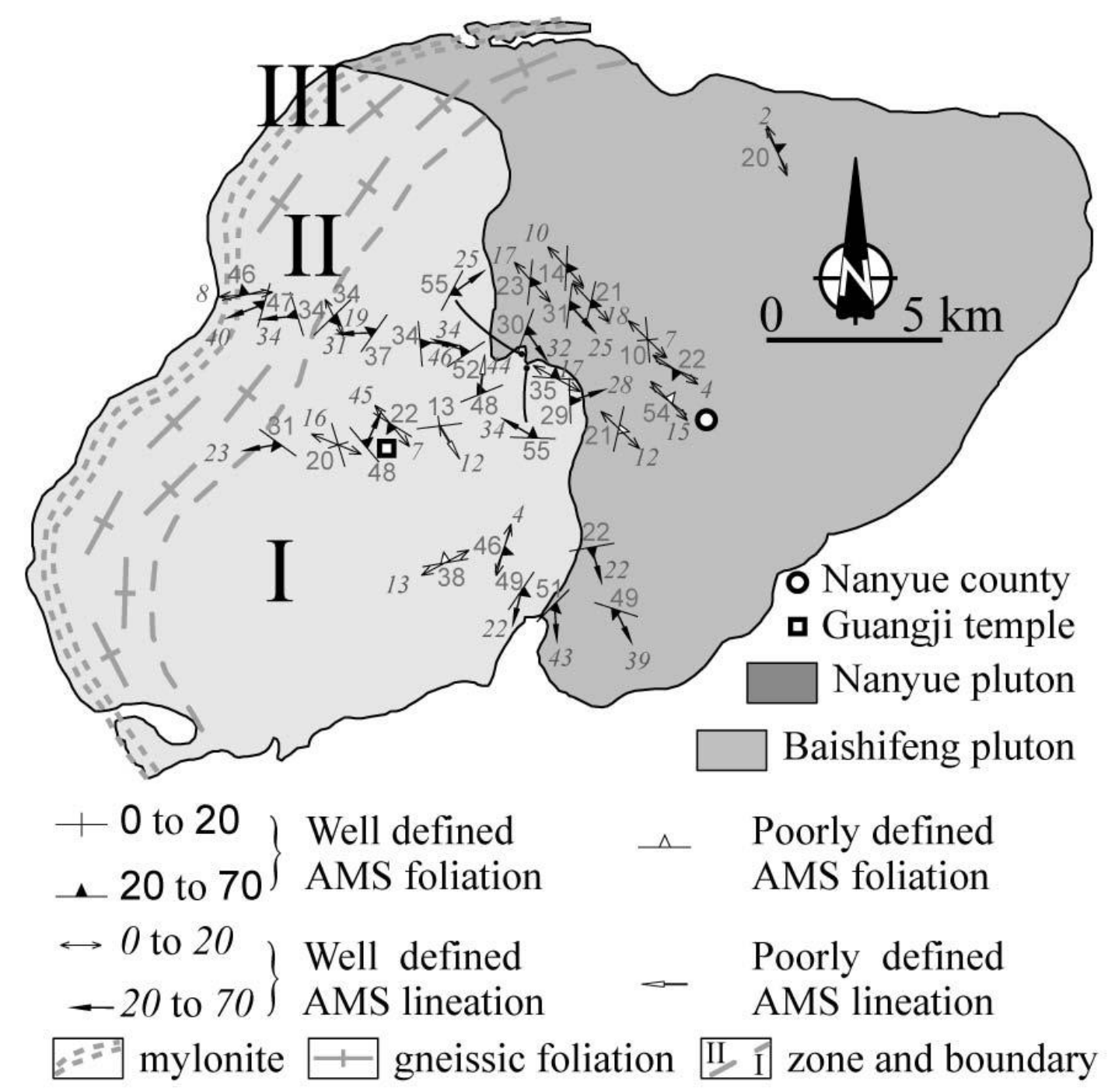

Figure 8. Map of magnetic fabric distribution of the Hengshan composite granitic massif. 

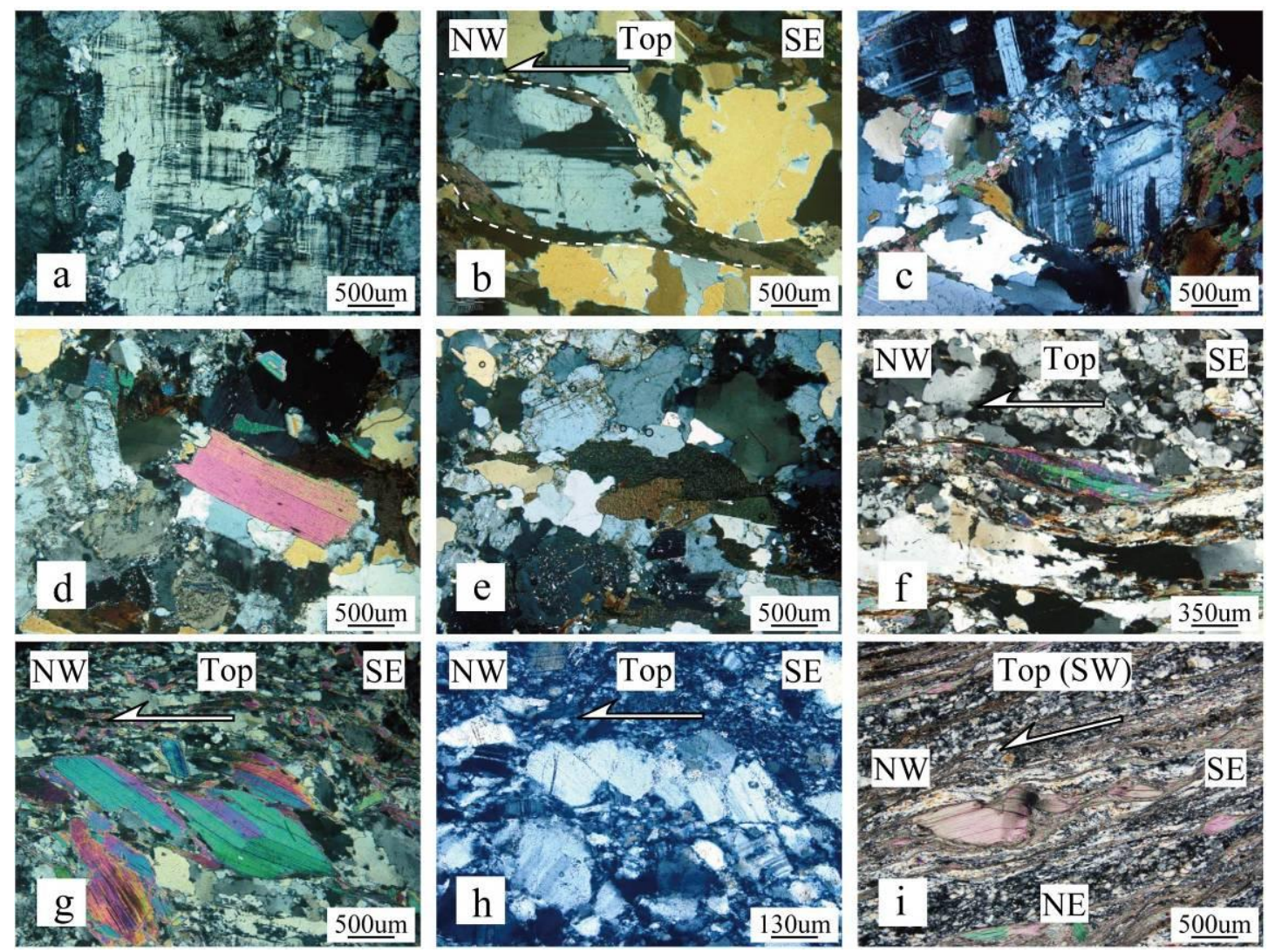

Figure 9. Microscopic observation on the Hengshan massif. Pictures a to $\mathrm{c}$ are from

the Nanyue pluton, and d to i from the Baishifeng pluton. All thin sections are located in fig. $1 b$.

a: Cataclased K-Feldspar (Location 9); b: Sigmoidal biotite and feldspar, indicating a top-to-the-NW shear sense (Location 2); c: Mechanical twins indicating a post-solidus deformation developed in feldspar (Location 12); d: Magmatic texture (Location 4); e: Subgrains and wavy extinction of quartz indicating a slight magmatic deformation in the central part of the pluton (Location 10); f: Sigmoidal shape of muscovite indicating a top-to-the-NW shear sense in the western part of the pluton (Location 5); g: Mica fish structure in the western part of the pluton indicating a top-to-the-NW shear sense (Location 11), h: Bookshelf structure in feldspar of ultramylonite indicating a top-to-the-NW shear sense (Location 6), i: Sigmoidal muscovite of ultramylonite along the southwestern boundary of the Baishifeng pluton indicating a top-to-the-NW shear sense (Location 8). 

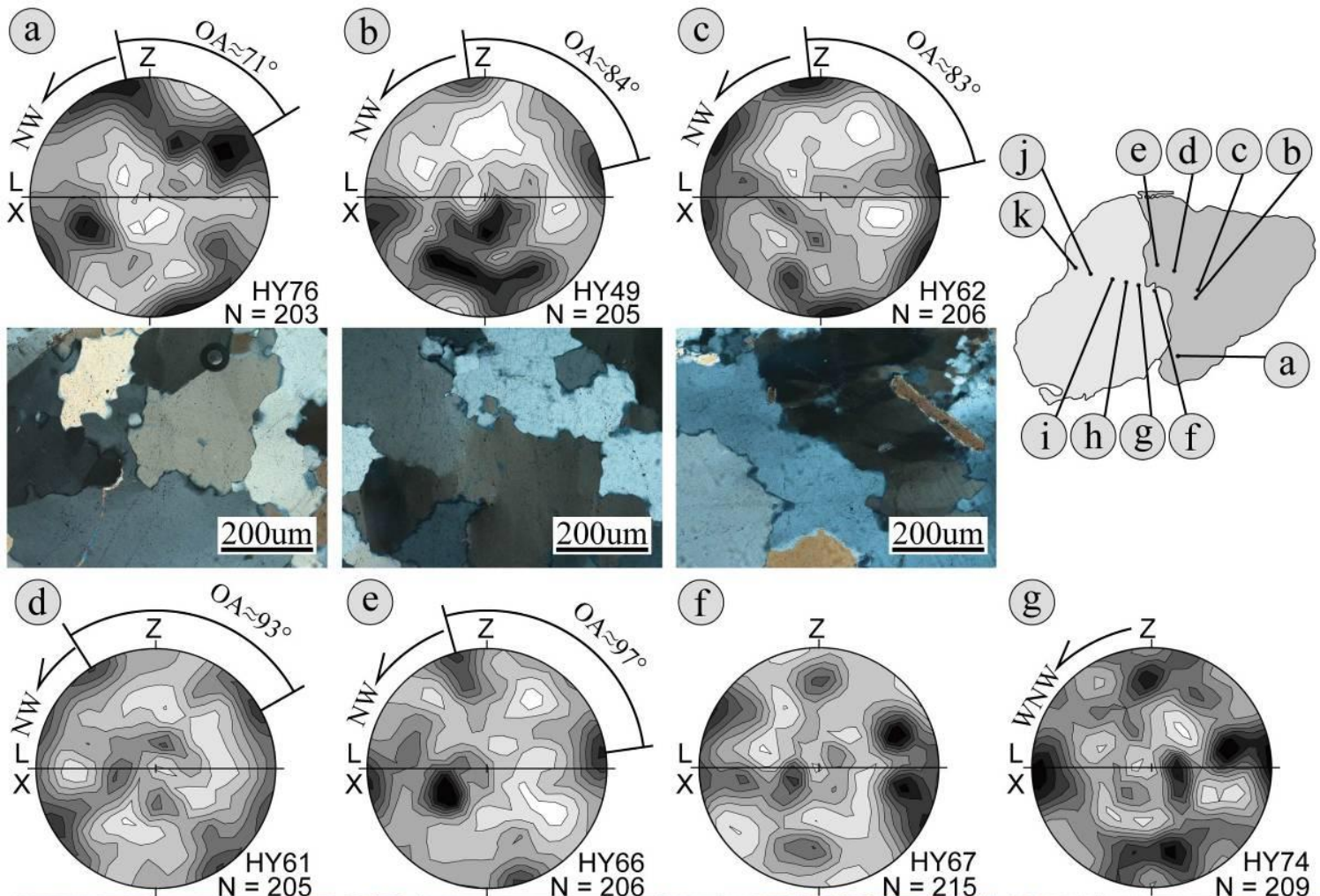

(f)
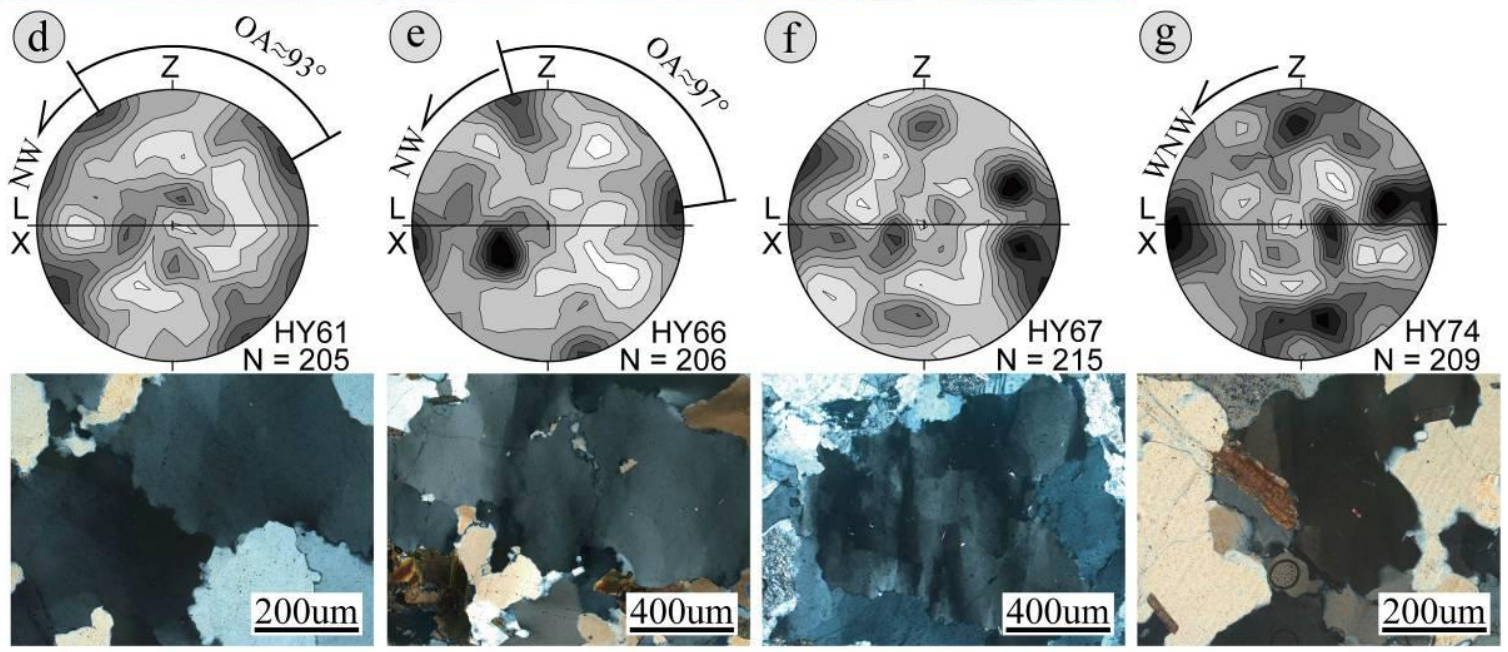

(h)
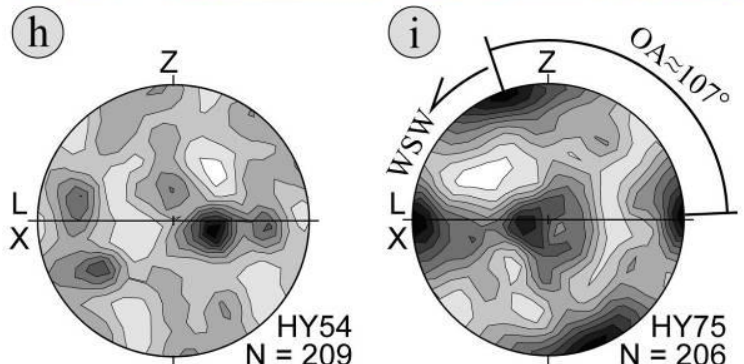

(i)
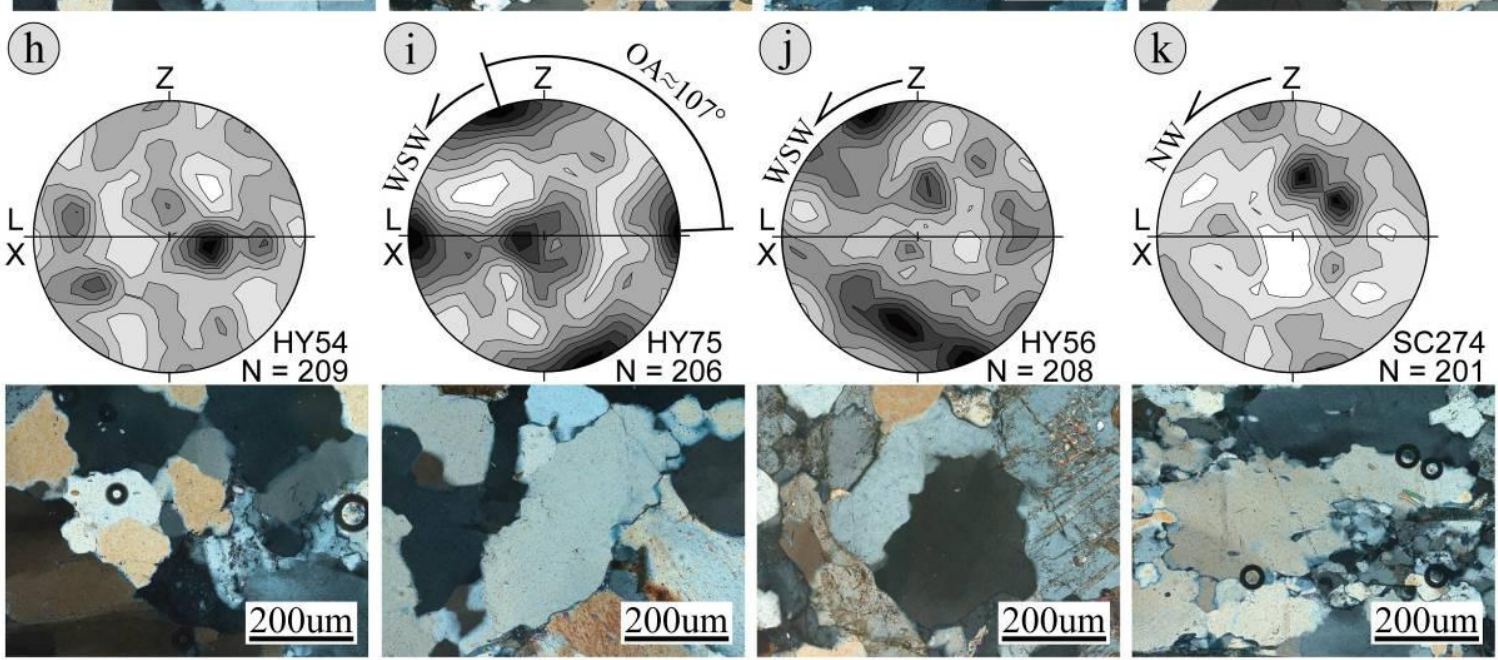

Figure 10. Quartz C-axis fabrics measured by universal stage (N: number or

measurements) and quartz texture of the Hengshan composite granitic massif. OA:

opening angle between the quartz $\mathrm{C}$-axis maxima. Refer to Figure 6 for the sample detailed locations and the comparison between $\mathrm{C}$-axis preferred orientation and the 
magnetic fabric. 


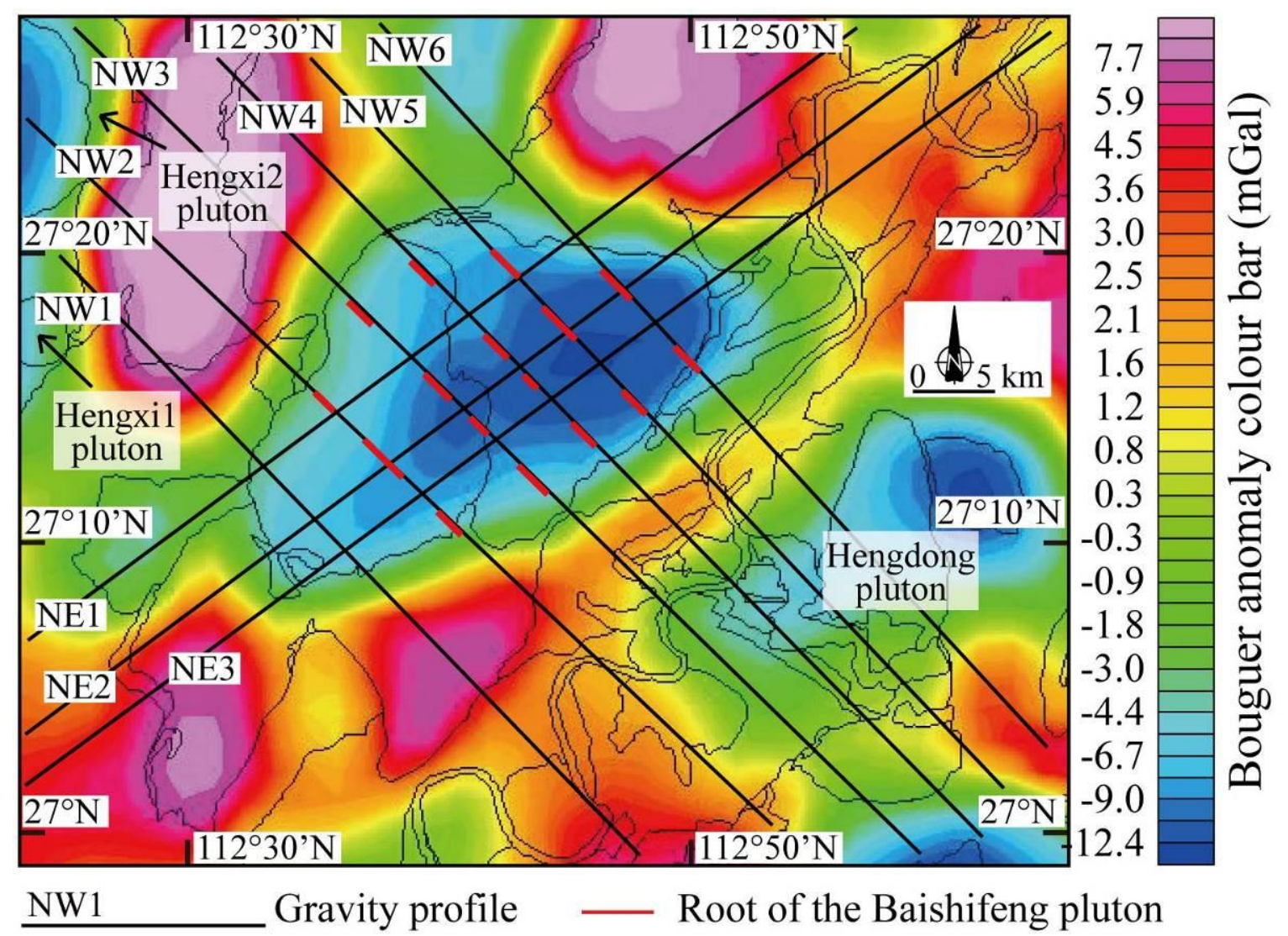

Figure 11. Residual Bouguer anomaly map of the Hengshan composite massif and its surrounding area with location of the modeled gravity profiles shown in Fig. 12. 

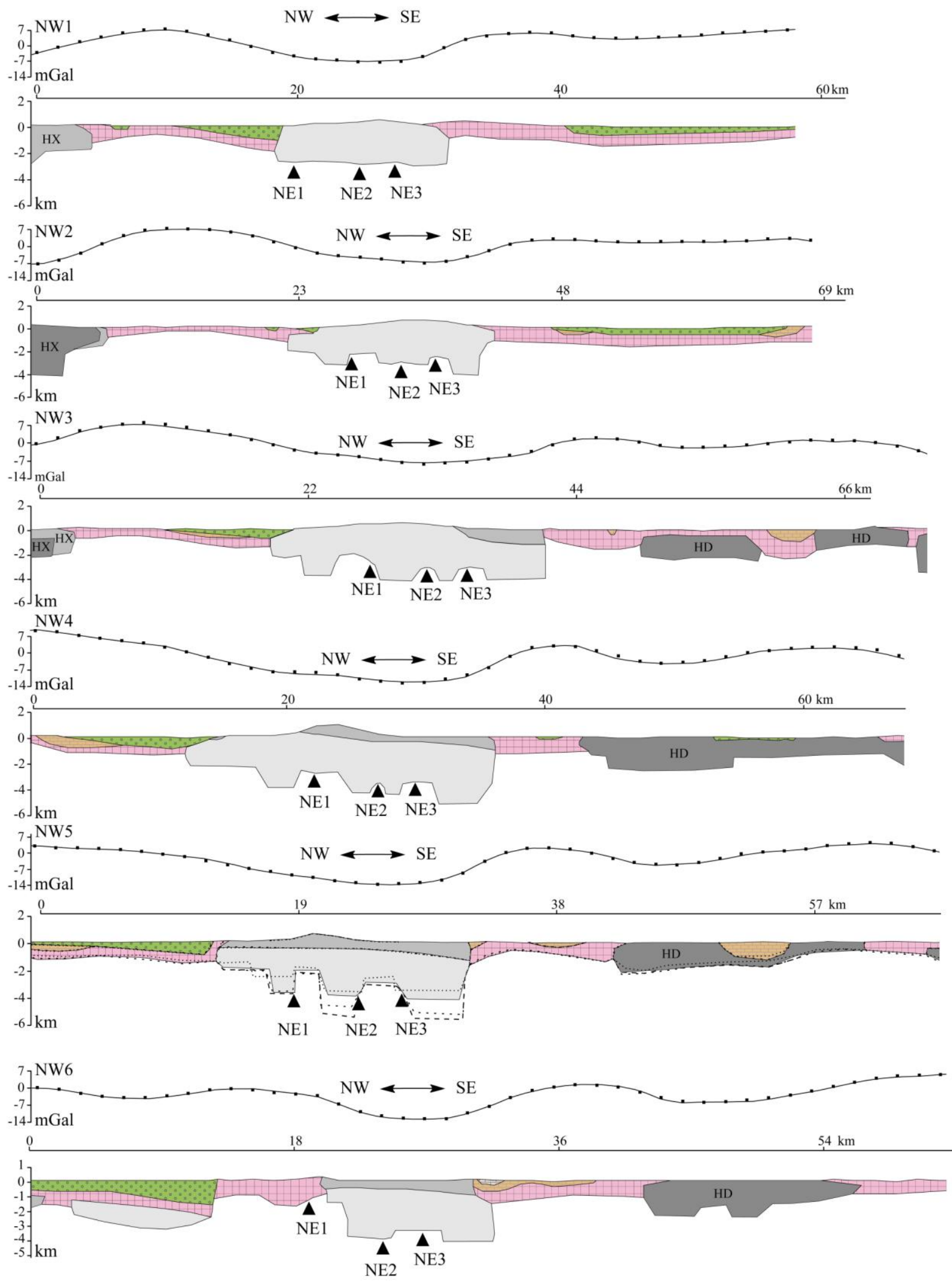

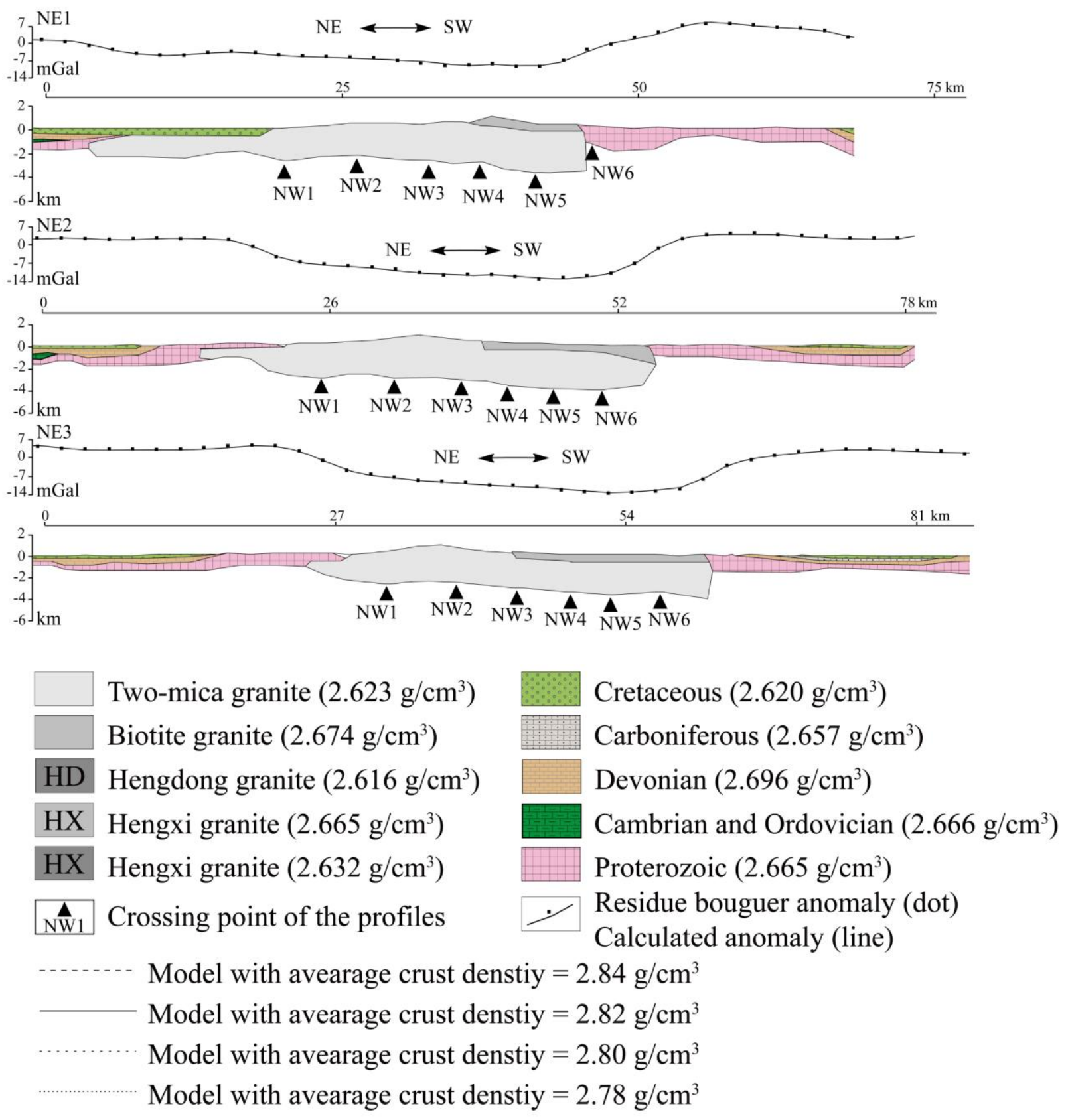

Figure 12. Forward gravity modeling conducted along 6 NW-SE profiles and 3 NE-SW profiles across the Hengshan composite granitic massif (see Fig. 11 for profile locations). 


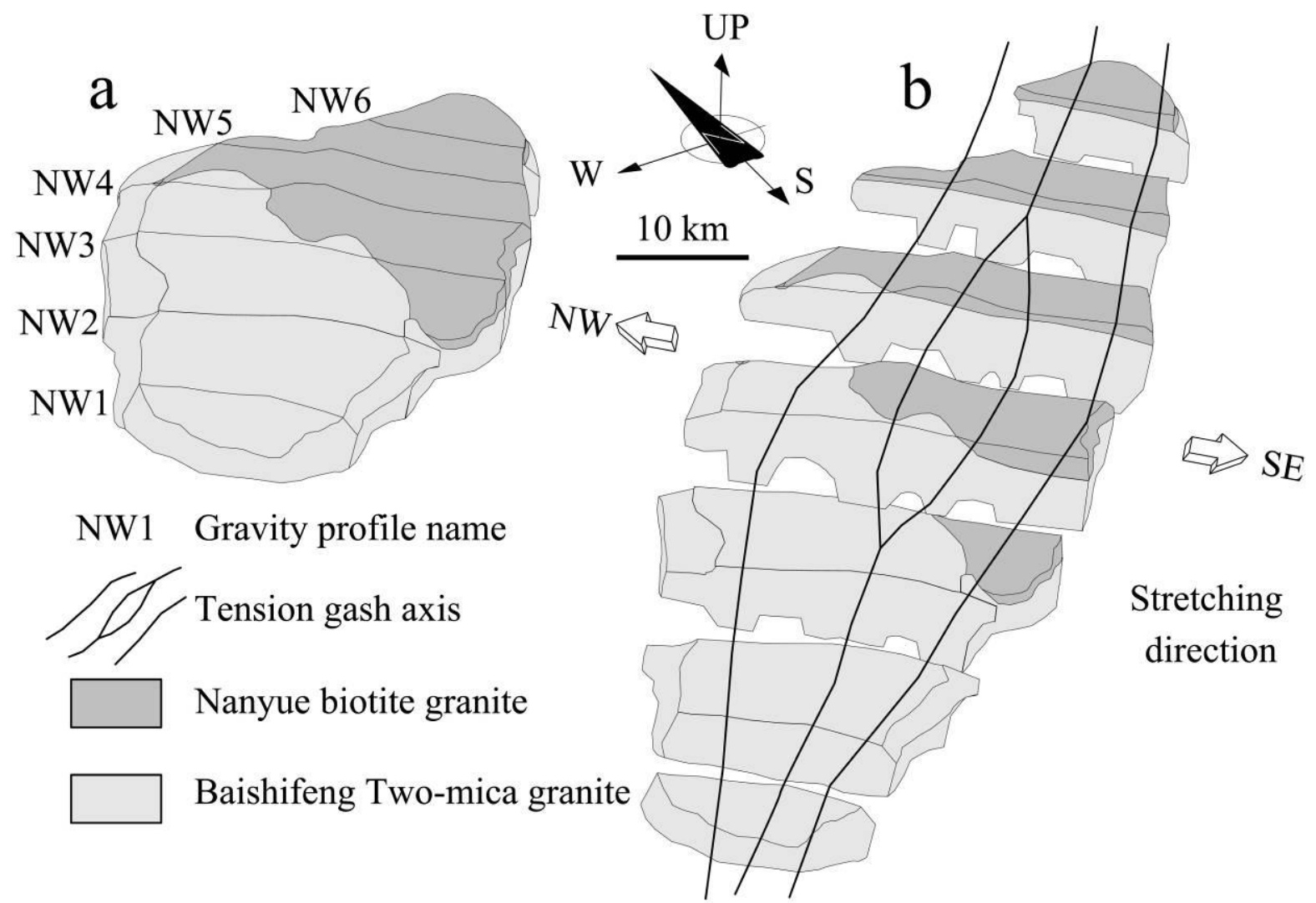

Figure 13. 3D shape of the Hengshan composite massif. 

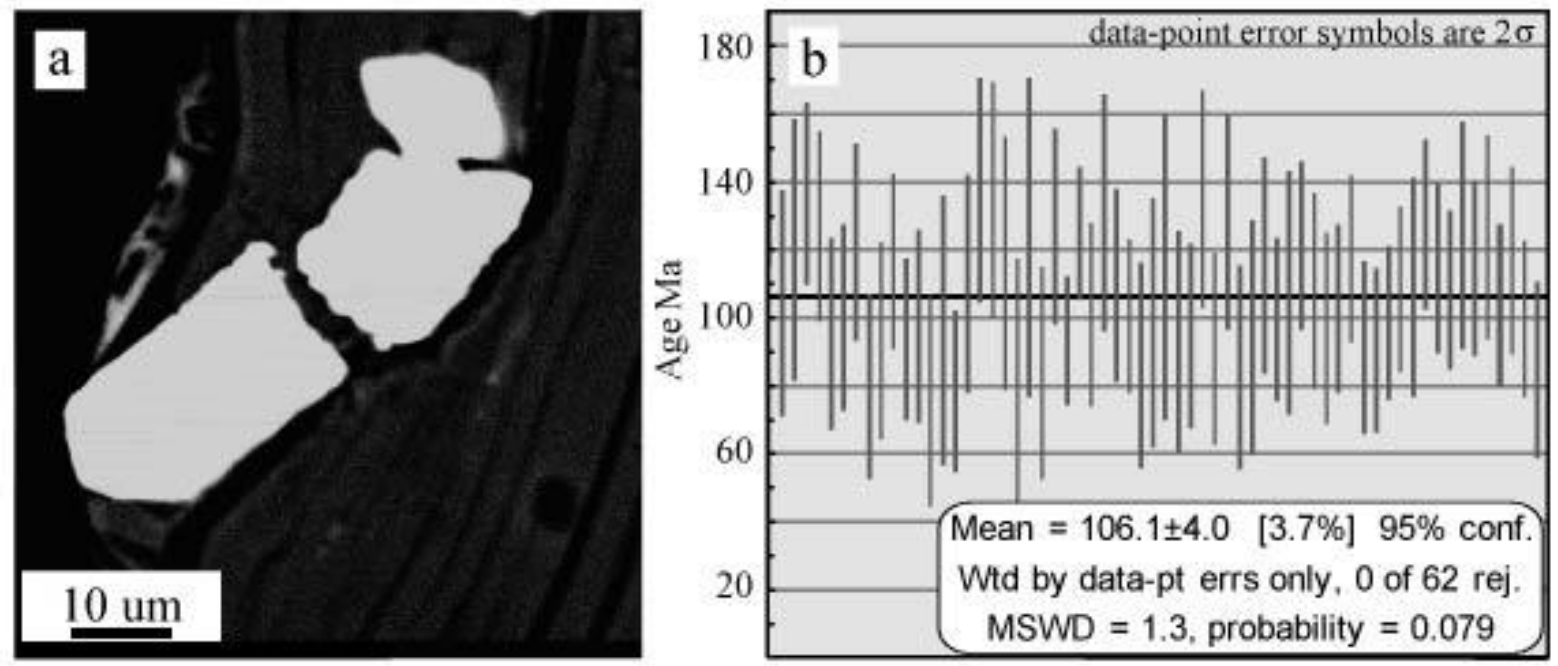

Figure 14. Monazite U-Th-Pb chemical dating of the Baishifeng two-mica pluton involved in the West Hengshan shear zone. 

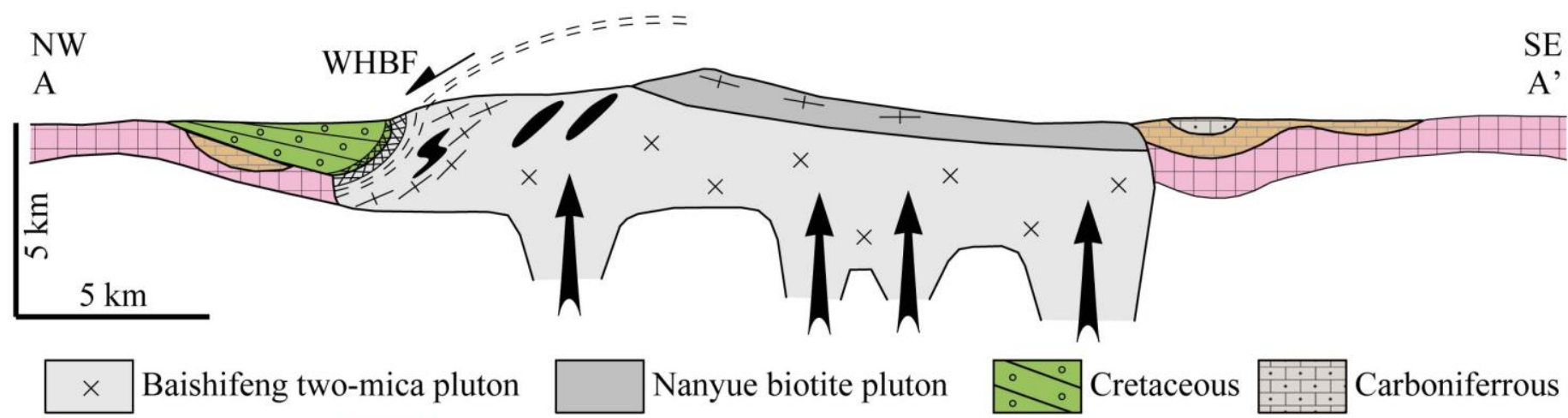

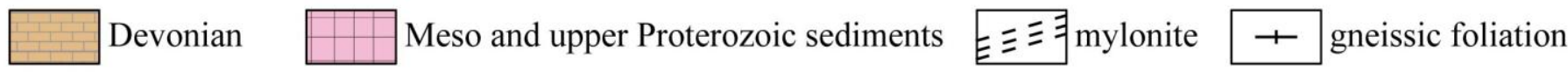
Paleo-Proterozoic or older crystalline basement schlieren and magmatic foliation $S$ Deformed country rock xenolith magma injection

Figure 15. Cross section through the Hengshan composite massif and its country rocks (location shown in Fig. 1b). 
Table 1 The results of AMS measurements of the Hengshan granitic massif

\begin{tabular}{|c|c|c|c|c|c|c|c|c|c|c|c|c|c|c|c|}
\hline \multirow{2}{*}{ site } & \multicolumn{2}{|c|}{ Coordinates } & \multirow[b]{2}{*}{ Lith } & \multirow[b]{2}{*}{$\mathrm{n}$} & \multirow{2}{*}{$\begin{array}{c}\mathrm{Km} \\
\left(10^{-4} \mathrm{SI}\right)\end{array}$} & \multirow[b]{2}{*}{$\mathrm{P}_{\mathrm{J}}$} & \multirow[b]{2}{*}{$\mathrm{T}$} & \multicolumn{4}{|c|}{$\mathrm{K}_{1}$} & \multicolumn{4}{|c|}{$\mathrm{K}_{3}$} \\
\hline & $\begin{array}{c}\text { Long } \\
\left({ }^{\circ} \mathrm{E}\right)\end{array}$ & $\begin{array}{l}\text { Lat } \\
\left({ }^{\circ} \mathrm{N}\right)\end{array}$ & & & & & & $\begin{array}{c}\text { Dec } \\
\left({ }^{\circ}\right)\end{array}$ & $\begin{array}{l}\text { Inc } \\
\left({ }^{\circ}\right)\end{array}$ & $\begin{array}{c}\alpha_{95 \max } \\
\left({ }^{\circ}\right)\end{array}$ & $\begin{array}{c}\alpha_{95 \min } \\
\left(^{\circ}\right)\end{array}$ & $\begin{array}{c}\text { Dec } \\
\left({ }^{\circ}\right)\end{array}$ & $\begin{array}{c}\text { Inc } \\
\left({ }^{\circ}\right)\end{array}$ & $\begin{array}{c}\alpha_{95 \max } \\
\left({ }^{\circ}\right)\end{array}$ & $\begin{array}{c}\alpha_{95 \min } \\
\left({ }^{\circ}\right)\end{array}$ \\
\hline \multicolumn{16}{|c|}{ Nanyue pluton } \\
\hline HY49 & 27.25 & 112.72 & BG & 9 & 144 & 1.034 & -0.161 & 317 & 15 & 17 & 4 & 217 & 36 & 38 & 3 \\
\hline HY50 & 27.24 & 112.71 & BG & 11 & 143 & 1.036 & -0.294 & 315 & 12 & 13 & 8 & 77 & 69 & 62 & 10 \\
\hline HY58 & 27.32 & 112.75 & BG & 8 & 84.1 & 1.021 & 0.163 & 338 & 2 & 31 & 14 & 243 & 70 & 20 & 14 \\
\hline HY60 & 27.29 & 112.69 & BG & 9 & 119 & 1.09 & 0.395 & 138 & 10 & 8 & 3 & 273 & 76 & 8 & 4 \\
\hline HY61 & 27.28 & 112.70 & BG & 6 & 106 & 1.073 & -0.009 & 137 & 18 & 9 & 1 & 283 & 69 & 11 & 2 \\
\hline HY62 & 27.27 & 112.72 & BG & 7 & 110 & 1.042 & -0.156 & 134 & 7 & 7 & 1 & 265 & 80 & 13 & 4 \\
\hline HY63 & 27.26 & 112.72 & BG & 5 & 105 & 1.046 & 0.04 & 123 & 4 & 9 & 5 & 23 & 68 & 11 & 7 \\
\hline HY64 & 27.28 & 112.69 & BG & 6 & 149 & 1.088 & 0.077 & 137 & 25 & 4 & 3 & 277 & 59 & 6 & 4 \\
\hline HY65 & 27.27 & 112.68 & BG & 9 & 135 & 1.103 & 0.222 & 145 & 25 & 5 & 3 & 290 & 61 & 6 & 4 \\
\hline HY66 & 27.28 & 112.68 & BG & 6 & 190 & 1.13 & 0.491 & 138 & 17 & 7 & 2 & 276 & 67 & 7 & 3 \\
\hline HY76 & 27.19 & 112.67 & TMG & 12 & 164 & 1.035 & -0.355 & 154 & 39 & 10 & 6 & 18 & 41 & 23 & 6 \\
\hline HY77 & 27.19 & 112.70 & BG & 9 & 188 & 1.047 & -0.004 & 176 & 43 & 8 & 2 & 315 & 39 & 8 & 4 \\
\hline HY81 & 27.21 & 112.70 & BG & 8 & 178 & 1.033 & -0.077 & 165 & 22 & 14 & 6 & 350 & 68 & 19 & 4 \\
\hline \multicolumn{16}{|c|}{ Baishifeng pluton } \\
\hline HY51 & 27.25 & 112.69 & TMG & 7 & 48.9 & 1.037 & -0.188 & 71 & 28 & 17 & 5 & 268 & 61 & 18 & 6 \\
\hline HY52 & 27.26 & 112.69 & TMG & 8 & 60.4 & 1.066 & 0.147 & 299 & 17 & 31 & 4 & 184 & 55 & 12 & 8 \\
\hline HY53 & 27.26 & 112.68 & TMG & 8 & 62.7 & 1.05 & -0.049 & 54 & 32 & 7 & 5 & 298 & 35 & 15 & 4 \\
\hline HY54 & 27.26 & 112.65 & TMG & 11 & 45.3 & 1.082 & 0.456 & 96 & 34 & 16 & 6 & 265 & 56 & 15 & 5 \\
\hline HY55 & 27.27 & 112.63 & TMG & 5 & 40.7 & 1.102 & 0.386 & 154 & 19 & 37 & 2 & 316 & 70 & 6 & 2 \\
\hline HY56 & 27.27 & 112.61 & TMG & 6 & 205 & 1.336 & 0.136 & 261 & 34 & 17 & 2 & 72 & 56 & 13 & 10 \\
\hline HY57 & 27.28 & 112.60 & TMG & 8 & 34.9 & 1.137 & 0.489 & 265 & 8 & 31 & 7 & 167 & 44 & 18 & 6 \\
\hline HY59 & 27.28 & 112.61 & TMG & 8 & 11.3 & 1.204 & 0.036 & 249 & 40 & 6 & 5 & 106 & 43 & 12 & 5 \\
\hline HY67 & 27.26 & 112.68 & TMG & 9 & 63 & 1.072 & 0.375 & 301 & 34 & 9 & 5 & 182 & 36 & 11 & 3 \\
\hline HY68 & 27.25 & 112.67 & TMG & 9 & 71.2 & 1.11 & 0.638 & 7 & 44 & 41 & 8 & 158 & 42 & 20 & 8 \\
\hline HY69 & 27.24 & 112.66 & TMG & 10 & 43.8 & 1.103 & 0.9 & 149 & 12 & 70 & 3 & 353 & 77 & 6 & 4 \\
\hline HY70 & 27.24 & 112.64 & TMG & 8 & 54 & 1.212 & 0.852 & 140 & 7 & 15 & 2 & 32 & 68 & 4 & 2 \\
\hline HY71 & 27.24 & 112.63 & TMG & 10 & 32.1 & 1.104 & 0.573 & 24 & 45 & 13 & 6 & 230 & 42 & 10 & 7 \\
\hline HY72 & 27.24 & 112.63 & TMG & 9 & 43.2 & 1.096 & -0.399 & 112 & 16 & 24 & 5 & 253 & 71 & 21 & 15 \\
\hline HY73 & 27.24 & 112.61 & TMG & 9 & 51.3 & 1.066 & -0.118 & 259 & 23 & 16 & 9 & 36 & 59 & 19 & 11 \\
\hline HY74 & 27.26 & 112.66 & TMG & 9 & 61.6 & 1.088 & 0.413 & 289 & 46 & 6 & 3 & 146 & 38 & 21 & 3 \\
\hline HY75 & 27.27 & 112.64 & TMG & 14 & 66.1 & 1.055 & -0.104 & 268 & 31 & 9 & 7 & 125 & 53 & 9 & 7 \\
\hline HY78 & 27.19 & 112.70 & BG & 12 & 70.9 & 1.088 & 0.715 & 194 & 22 & 10 & 3 & 304 & 41 & 4 & 3 \\
\hline HY79 & 27.20 & 112.67 & TMG & 8 & 13.9 & 1.048 & 0.603 & 196 & 4 & 33 & 5 & 290 & 44 & 11 & 5 \\
\hline HY80 & 27.20 & 112.66 & TMG & 9 & 50 & 1.03 & 0.14 & 62 & 13 & 47 & 15 & 170 & 52 & 30 & 24 \\
\hline
\end{tabular}

Site: sampling site, Lat: Latitude, long: Longitude, Lith: Lithology, Km: average susceptibility, $\mathrm{P}_{\mathrm{J}}$ : Susceptibility anisotropy degree, T: The shape parameter of the AMS ellipsoid, $\mathrm{K}_{1}$ : Magnetic lineation, $\mathrm{K}_{3}$ :The pole of the magnetic foliation, Inc: Inclination, Dec: Declination, $\alpha_{95} \max$ and $\alpha_{95} \min$ : The long and short axis of the confidence ellipsoid at 95\% level, BG: Biotite granite, TMG: Two-mica granite. 
Table 2 Rock densities and the thickness of the strata involved in the gravity modeling in the study area

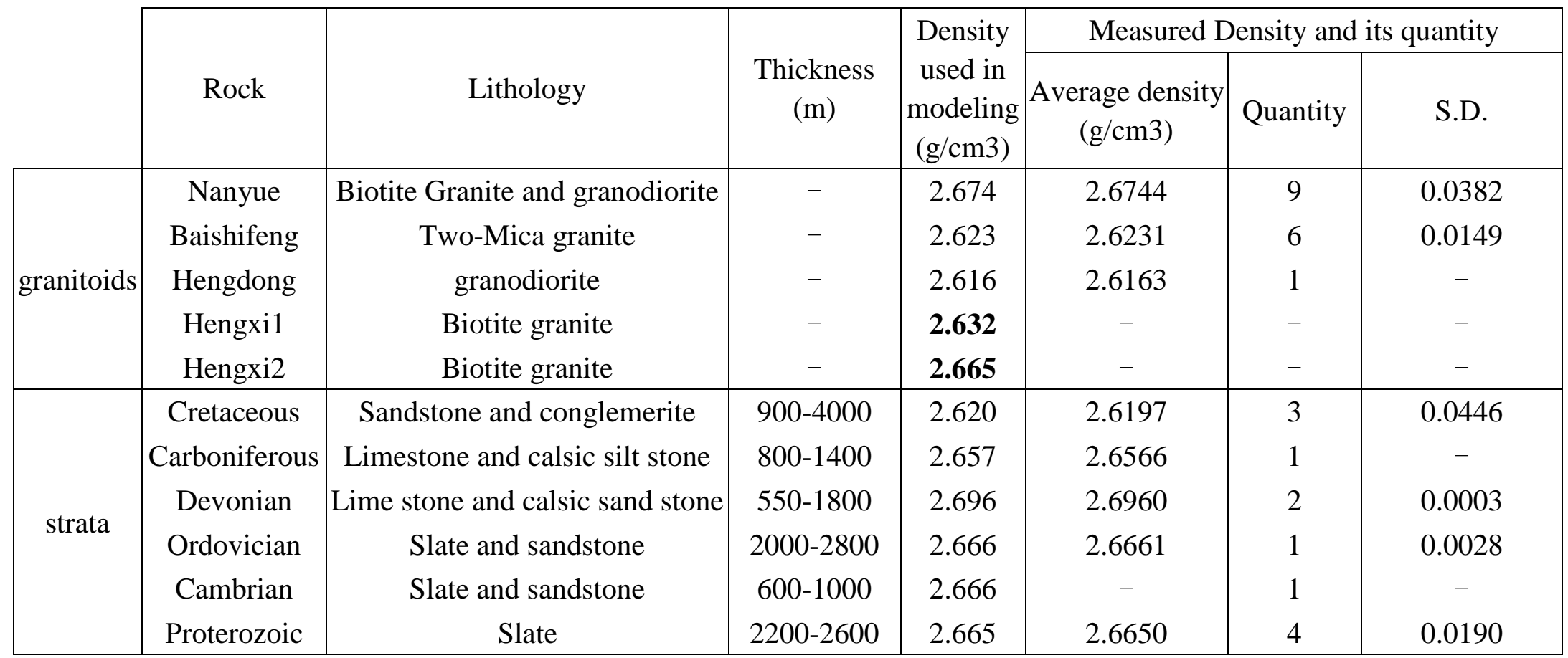

The figures of densities which are in bold is calculated by Nettleton/Parasnis method (Hinze et al., 2012), the rest densities are calculated by double weighting method. The thickness of the strata refer to (HNBGMR, 1973). 
Graphical abstract

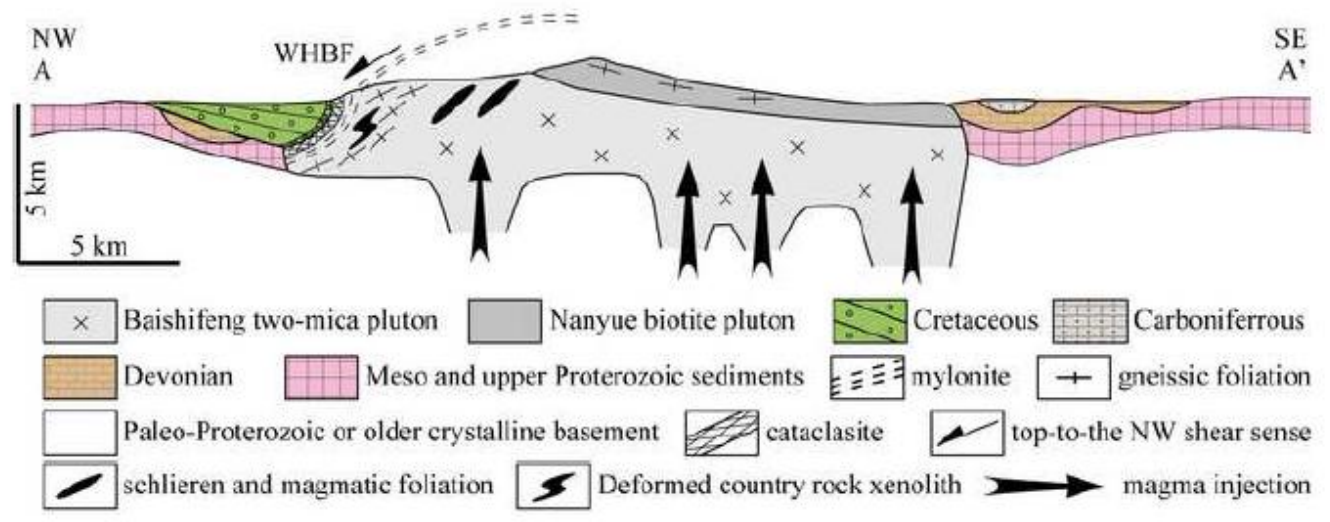




\section{Highlights}

- This work conducts a systematic structural and AMS investigation on Hengshan massif.

- This work interprets the Baishifeng pluton as a syntectonic pluton.

- The study area was under NW-SE stretching regime since $150 \mathrm{Ma}$. 